San Jose State University

SJSU ScholarWorks

Master's Theses

Master's Theses and Graduate Research

1997

\title{
Effect of selected browning inhibitors on artichoke (Cynara scolymus L.) heads
}

Iman H. Ababneh

San Jose State University

Follow this and additional works at: https://scholarworks.sjsu.edu/etd_theses

\section{Recommended Citation}

Ababneh, Iman H., "Effect of selected browning inhibitors on artichoke (Cynara scolymus L.) heads" (1997). Master's Theses. 1547.

DOI: https://doi.org/10.31979/etd.yzah-cw7r

https://scholarworks.sjsu.edu/etd_theses/1547

This Thesis is brought to you for free and open access by the Master's Theses and Graduate Research at SJSU ScholarWorks. It has been accepted for inclusion in Master's Theses by an authorized administrator of SJSU ScholarWorks. For more information, please contact scholarworks@sjsu.edu. 


\section{INFORMATION TO USERS}

This manuscript has been reproduced from the microfilm master. UMI films the text directly from the original or copy submitted. Thus, some thesis and dissertation copies are in typewriter face, while others may be from any type of computer printer.

The quality of this reproduction is dependent upon the quality of the copy submitted. Broken or indistinct print, colored or poor quality illustrations and photographs, print bleedthrough, substandard margins, and improper alignment can adversely affect reproduction.

In the unlikely event that the author did not send UMI a complete manuscript and there are missing pages, these will be noted. Also, if unauthorized copyright material had to be removed, a note will indicate the deletion.

Oversize materials (e.g., maps, drawings, charts) are reproduced by sectioning the original, beginning at the upper left-hand corner and continuing from left to right in equal sections with small overlaps. Each original is also photographed in one exposure and is included in reduced form at the back of the book.

Photographs included in the original manuscript have been reproduced xerographically in this copy. Higher quality 6" $x$ 9" black and white photographic prints are available for any photographs or illustrations appearing in this copy for an additional charge. Contact UMI directly to order.

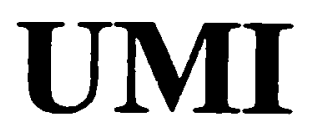

A Bell \& Howell Information Company 
Non-positively Curved Squared Complexes Aperiodic Tilings and Non-residually Finite Groups

\author{
Daniel T. Wise
}

\begin{abstract}
A DISSERTATION
PRESENTED TO THE FACULTY

OF PRINCETON UNIVERSITY

IN CANDIDACY FOR THE DEGREE

OF DOCTOR OF PHILOSOPHY
\end{abstract}

RECOMMENDED FOR ACCEPTANCE

BY THE DEPARTMENT OF MATHEMATICS

November 1996 
UMI Number: 1388165

UMI Microform 1388165

Copyright 1998, by UMI Company. All rights reserved.

This microiorm edition is protected against unauthorized copying under Title 17, United States Code.

\section{UMI \\ 300 North Zeeb Road \\ Ann Arbor, MI 48103}


(C) 1997

Imad H. Ababneh

ALL RIGHTS RESERVED 
APPROVED FOR THE DEPARTMENT

OF NUTRITION AND FOOD SCIENCE

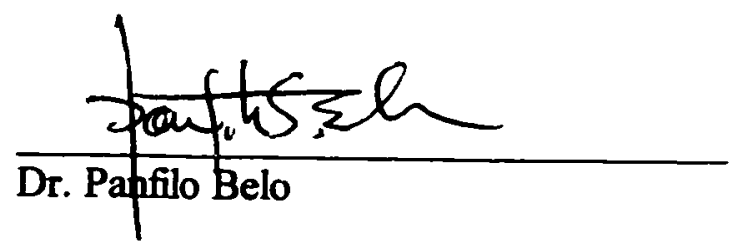

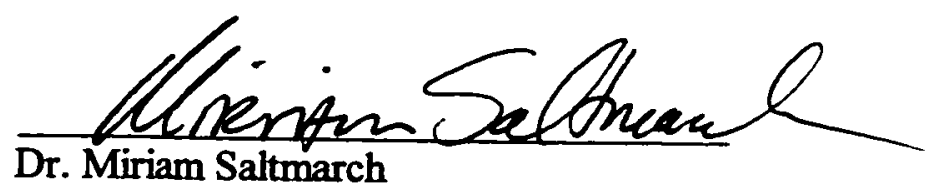

luyhofroud

Dr. Lucy McProud

APPROVED FOR THE UNIVERSITY William Fisk e 


\section{ABSTRACT \\ EFFECT OF SELECTED BROWNING INHIBITORS ON \\ ARTICHOKE (Cynara scolymus L.) HEADS \\ by Imad H. Ababneh}

The effectiveness of $0.5 \mathrm{M}$ citric acid $+1 \% \mathrm{H}_{3} \mathrm{PO}_{4}, 0.3 \mathrm{M} \mathrm{CaCl}+1 \% \mathrm{H}_{3} \mathrm{PO}_{4}$ and $0.5 \mathrm{M}$ citric acid $+0.3 \mathrm{M} \mathrm{CaCl}_{2}+1 \% \mathrm{H}_{3} \mathrm{PO}_{4}$ in controlling browning in fresh artichokes was tested. Artichoke disks were dipped into the three solutions for $1.5 \mathrm{~min}$. Treatments were visually evaluated at 0,3 , 6 , and 9 days of storage. Disks treated with $0.5 \mathrm{M}$ citric acid $+0.3 \mathrm{M} \mathrm{CaCl}+1 \% \mathrm{H}_{3} \mathrm{PO}_{4}$ solution showed the least degree of browning. However, visible browning and PPO activity did not correlate. To investigate the low degree of browning in $0.5 \mathrm{M}$ citric acid $+0.3 \mathrm{M} \mathrm{CaCl}_{2}+1 \% \mathrm{H}_{3} \mathrm{PO}_{4}$, water soluble phenolics, water insoluble phenolics and tissue $\mathrm{pH}$ were determined. However, these parameters and degree of browning also did not correlate. The $0.5 \mathrm{M}$ citric acid $+0.3 \mathrm{M}$ $\mathrm{CaCl}_{2}+1 \% \mathrm{H}_{3} \mathrm{PO}_{4}$ treatment was then applied to artichoke heads and the degree of browning was visually evaluated at 0,3 , and 6 days storage. The degree of browning in the treated artichoke heads was less than the control heads. A solution of $0.5 \mathrm{M}$ citric acid $+0.3 \mathrm{M} \mathrm{CaCl}_{2}+1 \% \mathrm{H}_{3} \mathrm{PO}_{4}$ can be used to prevent artichoke discoloration during cold storage. 


\section{ACKNOWLEDGMENTS}

I would like to acknowledge my graduate advisor, Dr. Panfilo Belo for his advice throughout this research. I would like to thank Dr. Miriam Saltmarch for her support and guidance throughout my graduate studies at San Jose State University. I also would like to thank Dr. Lucy McProud and Adina Naiman for their assistance with the editing of the manuscript. Finally, I would like to thank Judith Schallberger for her encouragement and support throughout the lab work of this study. 


\section{DEDICATION}

This humble work is dedicated to my family and Ann for their unconditional support, throughout the course of my studies in the United States. I love you. 


\section{PREFACE}

The following thesis is written in publication style. The second chapter is written in journal format and will be submitted to the Journal of Agricultural and Food Chemistry. Chapter I and III are written according to the guidelines in the Publication Manual of the American Psychological Association, 4th. edition, 1995. 


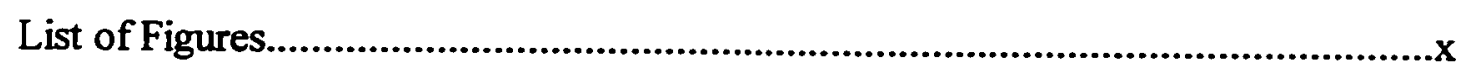

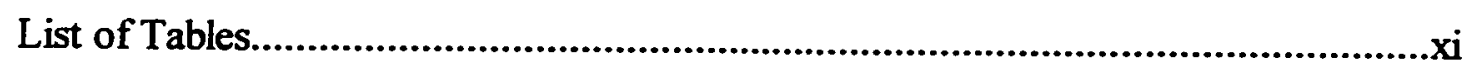

CHAPTER

1 INTRODUCTION AND REVIEW OF LITERATURE............................

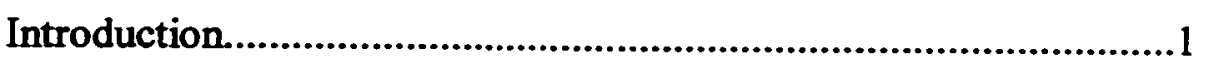

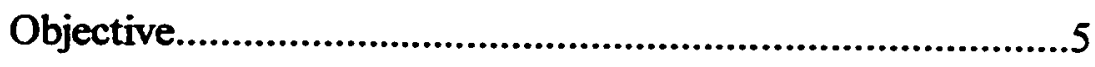

Significance of the Study...................................................5

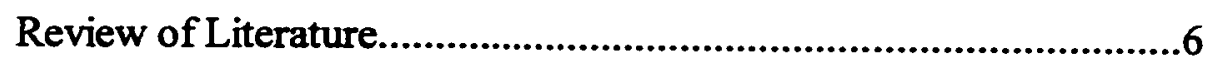

Polyphenol oxidase.........................................................6

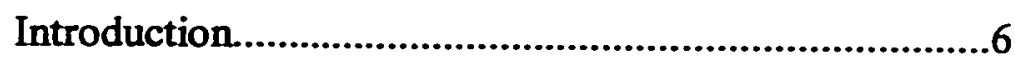

Extraction of PPO...................................................8

Determination of PPO Activity....................................9

Reaction Catalyzed by PPO........................................10

Substrates of PPO...................................................11

Inhibitors of PPO................................................... 12

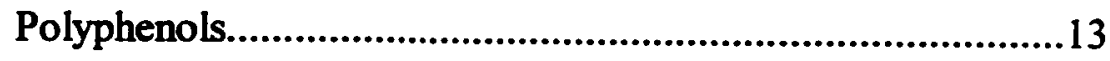

Fruits and Vegetables...................................................15

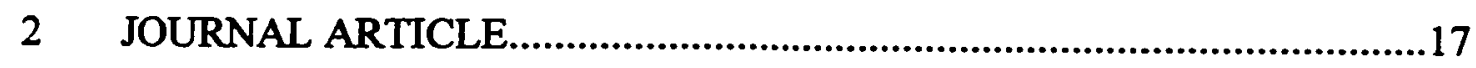

Authors' Title Page......................................................18 


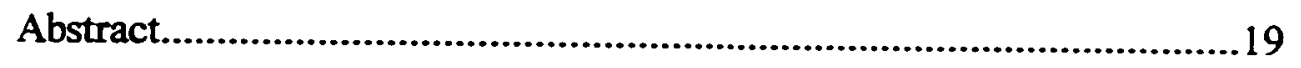

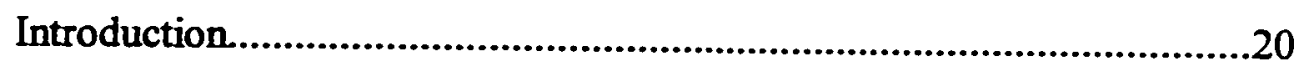

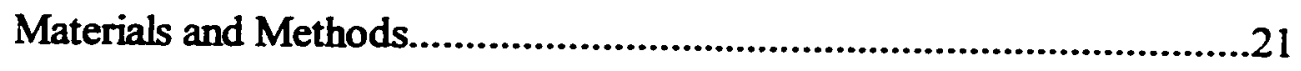

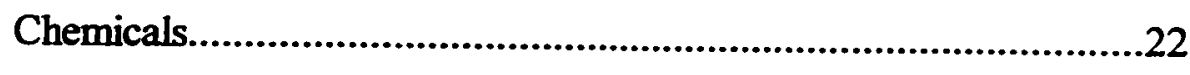

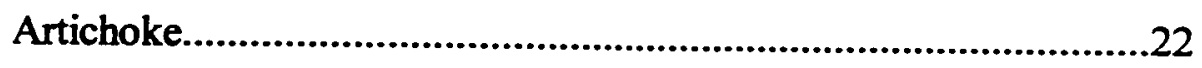

Samples Preparation, Dipping Treatment and Storage Conditions ..22

Degree of Browning...................................................................23

Polyphenol oxidase (PPO) Activity Determination..........................23

Effect of Dipping Solutions on the Activity of PPO Extracts..........24

Determination of $\mathrm{pH}$..............................................................25

Determination of Total Phenolics..................................................25

Enzymatic Determination of Water Soluble Phenolics.............26

Colorimetric Determination of Water Insoluble Phenolics......26

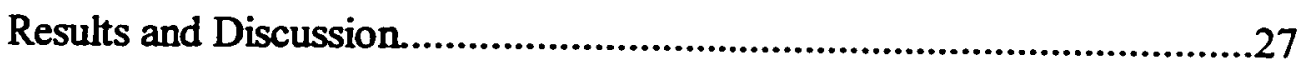

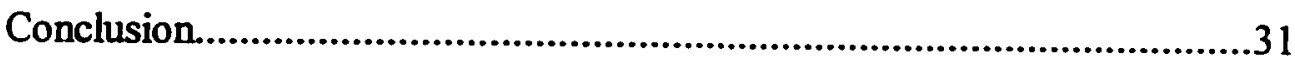

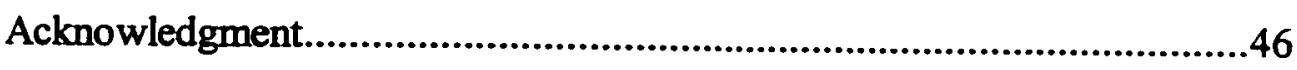

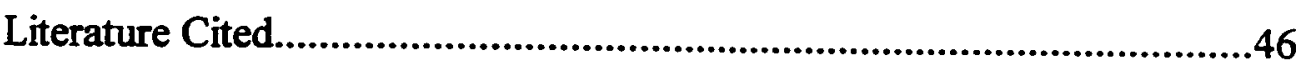

3 SUMMARY AND RECOMMENDATIONS....................................................48

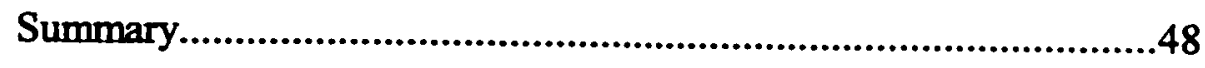

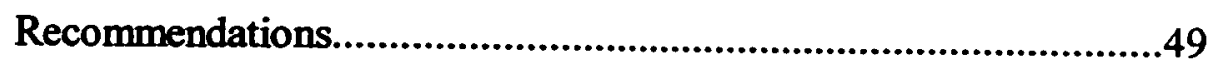

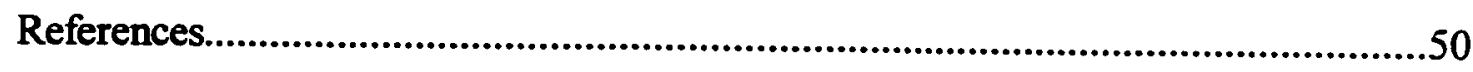




\section{List of Figures}

Figure

Page

1. Effects of dipping solutions on degree of browning at 0 day. .32

2. Effects of dipping solutions on degree of browning at 3 days of cold storage........33

3. Effects of dipping solutions on degree of browning at 6 days of cold storage........34

4. Effects of dipping solutions on degree of browning at 9 days of cold storage........35

5. Effects of $0.5 \mathrm{M}$ Citric acid $+0.3 \mathrm{M} \mathrm{CaCl}_{2}+1 \% \mathrm{H}_{3} \mathrm{PO}_{4}$ on degree of browning at 0 day of cold storage. .36

6. Effects of $0.5 \mathrm{M}$ Citric acid $+0.3 \mathrm{M} \mathrm{CaCl}_{2}+1 \% \mathrm{H}_{3} \mathrm{PO}_{4}$ on degree of browning 3 days of cold storage. .37

7. Effects of $0.5 \mathrm{M} \mathrm{Citric} \mathrm{acid}+0.3 \mathrm{M} \mathrm{CaCl}_{2}+1 \% \mathrm{H}_{3} \mathrm{PO}_{4}$ on degree of browning at 6 days of cold storage.

8. Changes of PPO activity in treated disks during cold storage.

9. Changes in $\mathrm{pH}$ during cold storage of control disks and $0.5 \mathrm{M}$ Citric acid $+0.3 \mathrm{M}$ $\mathrm{CaCl}_{2}+1 \% \mathrm{H}_{3} \mathrm{PO}_{4}$

10. Changes in water soluble phenolics during cold storage of control disks and $0.5 \mathrm{M}$ Citric acid $+0.3 \mathrm{M} \mathrm{CaCl}_{2}+1 \% \mathrm{H}_{3} \mathrm{PO}_{4}$

11. Changes in water in-soluble phenolics during cold storage of control disks and $0.5 \mathrm{M}$ Citric acid $+0.3 \mathrm{M} \mathrm{CaCl}_{2}+1 \% \mathrm{H}_{3} \mathrm{PO}_{4}$

12. Catechol standard curve 


\section{List of Tables}

Table

Page

1. Effects of Citric acid $+\mathrm{CaCl}_{2}+\mathrm{H}_{3} \mathrm{PO}_{4}$ and Citric $+\mathrm{H}_{3} \mathrm{PO}_{4}$ on the specific activity of crude PPO extract from artichoke stems without maintaining the optimal pH for PPO and using $0.05 \mathrm{M} \mathrm{Na-Phosphate} \mathrm{buffer} \mathrm{and} \mathrm{catechol} \mathrm{as} \mathrm{a} \mathrm{substrate.}$ . .44

2. Effects of Citric acid $+\mathrm{CaCl}_{2}+\mathrm{H}_{3} \mathrm{PO}_{4}$ and Citric $+\mathrm{H}_{3} \mathrm{PO}_{4}$ on the specific activity of crude PPO extract from artichoke stems and maintaining the optimal pH for PPO and using $0.5 \mathrm{M} \mathrm{Na}$-Phosphate buffer and catechol as a substrate. .45 


\section{CHAPTER 1}

\section{INTRODUCTION AND REVIEW OF LITERATURE}

\section{Introduction}

Browning reactions in foods are widespread (Vámos-Vigyázó, 1981; El-Shimi, 1993). For example, oxidative browning in fruits and vegetables occurs when food material is subjected to processing or mechanical injury (Vámos-Vigyázó, 1981). Browning reactions in foods can cause altered appearance, flavor, and nutritive value (ElShimi, 1993; Lattanzio, Cardinali, Di Venere, \& Palmieri, 1994). When browning enhances the appearance and flavor of a food product such as coffee, maple syrup, and toast it is desirable. However, browning is undesirable in fruits, vegetables, frozen foods and dehydrated foods because this oxidative browning results in off-flavors and poor appearance (Vámos-Vigyázó, 1981; El-Shimi, 1993). Oxidative browning of raw fruits and vegetables due to mechanical injury during postharvest handling and processing is an important cause of both quality loss and value loss in affected commodities (VámosVigyázó, 1981).

Basically, there are four types of browning reactions in foods: Maillard browning, caramelization, ascorbic acid oxidation, and phenolase browning. The first three are nonenzymatic in nature. The last, phenolase or enzymatic browning, occurs in ruptured fruit and vegetable tissues (Vámos-Vigyázó, 1981). The ruptured part of the fruit which is exposed to air undergoes a rapid darkening. This darkening or browning reaction results from the polyphenol oxidase (PPO) catalyzed oxidation of phenolic compounds to $o$-quinones which subsequently polymerize to form dark colored pigments (Mayer \& 
Harel, 1979). The rapid darkening of many fruits and vegetables such as apples, bananas, avocados, and potatoes is a serious problem when these foods are processed. Appropriate steps must be taken during food processing to protect these products from developing this type of browning.

Currently, the known methods of PPO inhibition are heating, sulfur dioxide and sulfite treatments, exclusion of oxygen, sodium chloride treatment, methylation of phenolase substrates, acid treatments such as boric acid, and treatment with borates (Vámos-Vigyázó, 1981). The use of browning inhibitors in food processing is restricted by special requirements such as non-toxicity, wholesomeness, and organoleptic effects. Effective browning prevention results are often achieved with mixtures of chemicals, however, the mechanism of antibrowning action is not well understood (Vámos-Vigyázó, 1981). Currently, the simplest method of inactivating PPO, along with all other enzymes present, is to apply heat because enzymes are proteins and therefore are easily denatured by heat. But several problems may arise with heat treatment of produce. For example, the fruits or vegetables become cooked which leads to unfavorable texture changes and the development of off-flavors (El-Shimi, 1993; Lattanzio, Linsalata, Palmieri, \& Van Sumere, 1989). Additionally, this kind of PPO inhibition cannot be applied to minimally processed fresh fruits and vegetables. Therefore, the most widely used method of controlling enzymatic browning in produce is the application of acids, especially the acids which naturally occur in plant tissues such as citric acid, malic acid, phosphoric acid, and ascorbic acid (El-Shimi, 1993). 
In general, acids lower the tissue $\mathrm{pH}$ and, thus, decrease the rate of browning. The optimum $\mathrm{pH}$ range of phenolase is $\mathrm{pH} 4-7$, while below $\mathrm{pH} 4$ there is no phenolase activity (Vámos-Vigyázó, 1981). Vámos-Vigyázó (1981) stated that ascorbic acid is the most acceptable inhibitor of PPO because it has no detectable flavor at the concentration employed which would interfere with the acceptability of the final processed product. Also, ascorbic acid has no corrosive action on metals, and it is an essential micronutrient (Vámos-Vigyázó, 1981; El-Shimi, 1993). Ascorbic acid reduces o-quinone to limit browning through a process known as "reaction deactivation" (Powers et al., 1958; Luh et al., 1975; as cited in El-Shimi, 1993). This mode of action can be described as forming a barrier against oxygen diffusion into the product. Sapers and Dougles (1987) stated that ascorbic acid is a more effective enzymatic browning inhibitor than are sulfites or erythorbic acid.

Many fruits and vegetables become brown or discolored after mechanical or physiological injury suffered during harvesting or storage (Mayer \& Harel, 1979). This reactivity raises important economic issues concerning the post-harvest physiology of plant commodities (Vámos-Vigyázó, 1981). During the processing and storage of fruits and vegetables, the need to prevent color changes or browning is important for producing acceptable foods with maximum freshness (Lattanzio et al., 1989). Produce browning is caused by the oxidation of certain phenolic compounds which are catalyzed by specific enzymes. PPO is the enzyme system mainly responsible for this oxidative browning (Mayer \& Harel, 1979). According to Mayer and Harel (1979), it is well established that 
PPO catalyses in vitro the hydroxylation of monophenols and the oxidation of $o$-diphenols to ortho-quinones. The physiological function of PPO in plants remains unknown (Lattanzio et al., 1989), although several hypotheses have been proposed. Some of the most important are the resistance of plant to microbial or viral infection, electron transport chain, and, probably, to adverse climate (Vámos-Vigyázó, 1981). Mayer (1987) stated that latent forms of PPO have been found in higher plants, and its location within the thylakoid has also been confirmed.

Artichokes are an expensive vegetable which are very susceptible to PPO browning. Artichokes are fat free and are a good source of dietary fiber, vitamin C, folate, and magnesium (Rainey \& Nyquist, 1997). Artichoke extracts have been used for centuries in European countries for their choleretic, ureolytic, diuretic and hypocholesterolemic action (Hammouda, El-Naser, \& Shahat, 1993). Fresh artichokes are prepared steamed or boiled whole, after which the fleshy bases of the outer bracts, the inner bracts, the receptacles, and portion of the floral stem may be eaten. Artichoke consumption in the United States has been historically concentrated among people of Southern Mediterranean ancestry (De Vos, 1992). In recent decades, however, Californians have become the principal consumers of fresh artichokes in the USA, accounting for about $50 \%$ of the total market (De Vos, 1992).

PPO is widely distributed in nature. Leoni, Palmieri, Lattanzio, \& Van Sumere (1990) reported the purification and characterization of the enzyme PPO in artichoke heads (Cynara scolymus L.). Artichoke Polyphenol oxidase (APPO) was described to be 
active toward $o$-diphenols (Leoni et al, 1990). APPO has an optimum pH between 5.07.0 and an optimum temperature around $20-30^{\circ} \mathrm{C}$ (Leoni et al., 1990). According to Lattanzio and Van Sumere (1987), the presence of phenols in artichokes is well established. Therefore, APPO could catalyze the production of quinones, giving rise to secondary reactions with the ultimate formation of intensely colored products. Thus, inhibiting APPO in fresh artichoke heads could be of great value in improving the overall quality and shelf life of artichokes.

\section{Objective}

The objective of this study was to evaluate the effectiveness of citric acid, calcium chloride, and citric acid+calcium chloride in the presence of phosphoric acid on the inhibition of browning in artichokes stored at refrigerator temperature.

\section{Significance of the Study}

The demand for minimally processed produce has increased due to increased health consciousness of consumers, diminished food preparation times, and increased purchasing power. Minimal or light processing of fruits and vegetables includes processing steps such as trimming, peeling, sectioning, slicing, and coring. Artichokes are a nutritious and popular vegetable in the USA (De Vos, 1992). However, the demand in the USA is for minimally processed fresh artichokes which are cooked at home or work. Fresh artichokes have never been sold minimally processed in microwavable packages, but a product of this type could be well received by American consumers and would be very 
convenient to use. Inhibition of the browning in cut artichokes is a crucial part of the research necessary to develop microwavable ready-to-eat artichokes.

Review of Literature

\section{Polyphenol oxidase}

\section{Introduction}

Polyphenol oxidase (PPO) has received attention from food chemists and food processors since its discovery (Mayer \& Harel, 1979), because this enzyme is involved in the enzymatic browning of many edible plant products, especially fruits, vegetables, and mushrooms, as well as crustaceans such as shrimp, lobster, and crab (Vámos-Vigyázó, 1981). Different names have been associated with PPO including tyrosinase, cresolase, catecholase, diphenolase and phenolase (Vámos-Vigyázó, 1981). In their recent revised nomenclature the commission on Enzymes of the International Union of Biochemistry (IUB) placed PPO into two key categories: (1) EC 1.14.18.1-monophenol monooxygenase (also known as tyrosinase) and; (2) EC 1.10.3.2 o-diphenols: $\mathrm{O} 2$ oxidoreductase (Mayer, 1987).

PPO is widely distributed in the plant and animal kingdom (Vámos-Vigyázó, 1981). Unlike animal PPO which is confined to the skin, hair, feathers, and eyes plant PPO is not restricted to any particular organ (Mayer \& Harel, 1979). Thus, foods that may contain PPO are derived mainly from plants, mushrooms and crustaceans (Vámos-Vigyázó, 1981). 
The distribution of PPO in edible plant products has been reviewed by several authors (Mayer \& Harel, 1979; Vámos-Vigyázó, 1981; Mayer, 1987). Furthermore, PPO has been recently isolated and studied in number of food commodities not previously reported inchuding Jerusalem artichokes (Zawistowski, Blank, \& Murray, 1986), artichokes (Leoni et al., 1990), Spanish papaya fruit (Cano, Lobo, Ancos, \& Galeazzi, 1996), and Indian pineapple fruit (Das, Bhat, \& Gowda, 1997).

The role of PPO in plants is ambiguous, because in healthy green tissues this enzyme exists in the inactive form (Mayer, 1987). Activation of PPO occurs during infection or mechanical injury resulting in quinone formation. These quinones undergo secondary polymerization reactions yielding a dark, insoluble polymer (Vámos-Vigyázó, 1981). The plant tissue 'impregnated' with these polymers provide a barrier for preventing the spread of infection in the plant (Mayer \& Harel, 1979; Vámos-Vigyázó, 1981). In this capacity, the enzyme affords resistance to plant infections by viruses, bacteria, fungi, and from mechanical damage.

The level of PPO in plants is dependent on the species, cultivar, maturity and age of each plant (Vámos-Vigyázó, 1981). Differences in PPO content have been found between cultivars of apples, grapes, eggplants, yam tubers, sweet potatoes and regular potatoes (Vámos-Vigyázó, 1981). Food processors, recently deprived of the application of sulfites to inhibit enzymatic browning, are now interested in varieties with lower PPO content, which are less susceptible to this type of discoloration (Vámos-Vigyázó, 1981). 


\section{Extraction of PPO}

Extraction of PPO from foods of plant origin is extremely difficult (Vámos-Vigyázó, 1981). Primarily, PPO isolation is difficult because both the enzyme and the substrate occur side by side in intact cells (Mayer \& Harel, 1979). PPO is located exclusively in the plastids of healthy plant tissue and is not activated until it crosses the plastid envelope (Mayer \& Harel, 1979). In contrast, the majority of phenolic compounds in higher plants are located in the vacuole which is distinct from the plastids (Vaughn \& Duke, 1984). Thus, it is important to carefully select methods of extraction and isolation of PPO which minimize or even eliminate any changes in enzyme structure and activity during its purification.

To minimize these problems, all extraction steps should be carried out in the cold at any rate below $0^{\circ} \mathrm{C}$ (Vámos-Vigyázó, 1981). Early researchers used lead acetate as a precipitant for polyphenols, but its use is limited because it does not precipitate all plant phenols and results in considerably lower PPO yields (Mayer \& Harel, 1979). More recently, insoluble polyvinyl pyrrolidone (PVP) has been used for removal of phenols during separation of subcellular fractions and in the initial purification steps of separating the enzyme from plants (Mayer \& Harel, 1979). However this technique, has its disadvantages such as it requires a large amount of PVP, an acidic $\mathrm{pH}$ during the extraction (maximum affinity for plant phenols occurs at pH 3.5), and a time-consuming pretreatment procedure prior to extraction. Acetone precipitation followed by buffer 
extraction is one of the methods often used as an initial step in isolation of the PPO (Vámos-Vigyázó, 1981; Lattanzio et al., 1989; Leoni et al., 1990; Lattanzio et al. 1994). This method is certainly advantageous because one can use it to obtain a crude enzyme preparation with a high yield and which is free of artifacts (Mayer \& Harel, 1979; VámosVigyázó, 1981). In order to prevent activation during buffer extraction, reducing agents or quinone couplers such as ascorbic acid, cysteine, sodium metabisulfite, sodium diethyldithiocarbamate, sodium tetrathiolate or thiourea, have been included (Mayer \& Harel, 1979; Vámos-Vigyázó, 1981).

\section{Determination of PPO Activity}

PPO activity can be determined by measuring: (1) the rate of substrate disappearance (Leoni et al, 1990; Lattanzio et al., 1994) and/or; (2) the rate of product formation (Zawistowski et al., 1986; Coseteng \& Lee, 1987; El-Shimi, 1993; Cano et al., 1996; Das et al., 1997). The latter can be determined spectrophotometrically by measuring the optical density of the colored compounds formed from the quinones. A wide variety of substrates can be used with this method, such as catechol (Zawistowski et al., 1986; Coseteng \& Lee, 1987; El-Shimi, 1993; Cano et al., 1996; Das et al., 1997). However, accurate determination of PPO activity continues to be a challenge in spite of the numerous methods described in the literature (Vámos-Vigyázó, 1981). This is because quinones formed during the course of the enzymatic reaction undergo secondary reactions with themselves, unreacted substrates, oxygen, other constituents, and the enzyme (Mayer 
\& Harel, 1979; Vámos-Vigyázó, 1981). These reactions lead to the formation of complex polymeric molecules interfering with the reliability of the assay (Vámos-Vigyázó, 1981). Also, the existence of other enzymes with similar molecular properties, such as laccase and peroxidase in plant tissues, may be mistaken for PPO activity during its determination (Maye- \& Harel, 1979; Vámos-Vigyázó, 1981). Enzymes show overlapping substrate specificities by being able to convert phenols to quinones. It is, therefore, very important to differentiate between PPO and the other enzymes to avoid confusion. A number of methods to distinguish between these enzymes have been reviewed by Mayer and Harel (1979) and Mayer (1987).

\section{Reaction Catalyzed by PPO}

PPO is a copper-containing enzyme capable of catalyzing two different types of reactions, the hydroxylation of monophenols to diphenols and the dehydrogenation of $o$ diphenols to o-quinones (Mayer \& Harel, 1979; Vámos-Vigyázó, 1981). The latter products subsequently undergo a series of non-enzymatic reactions to yield brown-black melanin pigment. These two enzymatic activities are referred to as monophenolase (hydroxylase or cresolase) and diphenolase (catecholase or oxidase), respectively (Mayer \& Harel, 1979).

The ratio of diphenols to monophenolase activity varies with the plant source, although diphenolase activity was generally found to be 5-10 times higher than monophenolase activity (Vámos-Vigyázó, 1981). Studies on Jerusalem artichoke PPO by 
Zawistowski et al. (1986) found the specific activity to be 10-50 times greater for the $o$ diphenol substrates, catechol, and chlorogenic acid, compared to monophenols, tyrosine and p-cresol. The substrate specificity of PPO is ambiguous (Mayer \& Harel, 1979). In addition to hydroxylase and oxidative activities, PPO from several plant sources has been reported to oxidize tri-, tetra and other polyphenols (Vámos-Vigyázó, 1981).

Experiment by Kubowitz (1938; as cited in Mayer \& Harel, 1979) established copper as a component of PPO which was essential for its overall activity. This was confirmed by the loss of PPO activity when copper was removed by potassium cyanide and was restored when copper was added (Kubowitz, 1938; as cited in Mayer \& Harel, 1979). These results were subsequently reported by other researchers for PPO isolated from many sources (Vámos-Vigyázó, 1981).

\section{Substrates of PPO}

Many reports on PPO were concerned with the specificity of the enzyme towards phenolic compounds (Mayer \& Harel, 1979). The most important natural phenolic substrates of PPO found in fruits and vegetables are catechins, cinnamic acid esters (e.g. chlorogenic acid), 3,4-dihydroxy phenylalanine (DOPA) and tyrosine (Vámos-Vigyázó, 1981). The type and position of substituents present on mono- and o-dihydroxy phenols are also important determinants of substrate reactivity. Monophenols are hydroxylated only if they have a $-\mathrm{CH}_{3}$ group in the para position (Mayer \& Harel, 1979; VámosVigyázó, 1981). 


\section{Inhibitors of PPO}

Inhibitors of PPO and the control of enzymatic browning has been the subject of continued interest and a challenge to the food processor. According to Mayer \& Harel (1979), PPO isolated from fruits and vegetables such as grapes, apples, and potatoes continue to receive the most research because they affect the quality of wine, juices, and processed potato tubers, respectively. Enzymatic browning is detrimental to the appearance, organoleptic properties, nutritional quality, and occasionally, the safety of food products (Vámos-Vigyázó, 1981).

A wide range of compounds are known to inhibit PPO, although their efficiency in controlling browning reactions is dependent on the nature and concentration of the inhibitor, the source of PPO, the substrate availability $\left(\mathrm{O}_{2}\right.$, phenolics), the $\mathrm{pH}$ and the temperature (Vámos-Vigyázó, 1981). The mode of action also varies, and in many cases, it is difficult to assign a single specific mechanism of action for an inhibitor (VámosVigyázó, 1981). For example, some inhibitors act simultaneously on the enzyme, substrate, and the product. Aside from any economic feasibility, the use of effective browning inhibitors in food processing is restricted due to toxicity problems, effects on taste, flavor, texture, and wholesomeness of the food product (Vámos-Vigyázó, 1981).

With respect to inhibitors acting directly on the enzyme, several modes of action have been recognized (Mayer \& Harel, 1979; Vámos-Vigyázó, 1981). Since PPO is a metalloprotein, it can be inhibited by chelating agents such as cyanide, carbon monoxide, 
sodium diethyl-dithiocarbamate (DIECA), tropolone, 2-mercaptobenzothiazole, azide, potassium methyl xanthate and EDTA (Vámos-Vigyázó, 1981).

\section{Polyphenols}

Polyphenols confer on fruits, vegetables and other plant food qualities that are both desirable and undesirable, and are significantly absent in animal foods (Ranganna, 1978). These compounds consist of two groups: viz flavonoids and cinnamic acid derivatives. Flavonoids form the broad major group and are characterized by the presence of a C6-C3C6 carbon skeleton consisting of the two aromatic rings linked by an aliphatic three carbon chain (Ranganna, 1978). This skeleton is made up of two biogenetically distinct fragments: the C6-C3 fragment that contains the B ring; and the C6 fragment which forms the A ring. The classification is made on the basis of state of oxidation of the aliphatic fragment of the basic skeleton. The hydroxylation pattern of A and B nuclei and the degree of polymerization of the C6-C3-C6 unit results in a large number of different of polyphenolic compounds. The major flavonoids of plants are the anthocyanins, lecucoanthocyanins, flavones, and flavonols (Ho, 1992). Accompanying these major flavonoids are the minor flavonoids, chlacones, and flavonones (Rangana, 1978). The cinnamic acid derivatives are not flavonoids in the strict sense, however, they are related to the flavonoids by virtue of the C6-C3 (B-ring) unit of the flavonoid (Rang anna, 1978).

Phenolic compounds are closely associated with the sensory and nutritional quality of fresh and processed foods (Mayer \& Harel, 1979; Vámos-Vigyázó, 1981). The enzymatic 
browning reaction of phenolic compounds, catalyzed by PPO, is of vital importance to fruit and vegetable processing due to the formation of undesirable color, flavor, and loss of nutrients (Mayer \& Harel, 1979; Vámos-Vigyázó, 1981). The enzymatic browning reaction in fruits and vegetables often has been considered to be a linear function of the total phenolic content and the PPO activity (Ho, 1992). However, Lee (1992) showed that the rate of browning in fruit products is not a linear function of the total phenolic content and that the browning of fruits depends on the concentration and nature of the polyphenol compounds that are present.

A common approach to prevent food and beverage browning has been to use antibrowning agents (Vámos-Vigyázó, 1981; El-Shimi, 1993). The most widespread antibrowning agents used in the food and beverage industries are sulfites (VámosVigyázó, 1981). However, due to the health risks of sulfiting agents, the Food and Drug Administration has banned or limited the use of sulfites in certain foods (Vámos-Vigyázó, 1981). Oxidative changes of polyphenols during processing are important for the development of color and flavor in certain foods (El-Shimi, 1993). Browning of polyphenols is a natural process of cocoa fermentation (Ho, 1992). For the manufacture of black tea, the tea leaves are crushed, causing polyphenoloxidase-dependant oxidative polymerization and leading to the formation of theaflavins and thearubigins, the orange and red pigments of black tea (Ho, 1992). Phenolic compounds are ubiquitous in plant foods and a significant quantity is consumed in our daily diet. The antioxidant activities of phenoïc compounds have been recognized for decades, and research and development on 
the use of natural substances or food ingredients containing phenolic antioxidants will continue to be of great interest to the food industry (Ho, 1992). Biological activities of phenolic compounds have become well known in recent years (Ho, 1992). The most important biological activity of phenolic compounds is probably their many observed inhibitory effects on mutagenesis and carcinogenesis (Ho, 1992).

\section{Fruits and Vegetables}

Fruits and vegetables contain a wide variety of phenolic compouruds (VámosVigyázó, 1981). However, only a relatively small number of these phenolic compounds serve as a substrate to PPO (Vámos-Vigyázó, 1981). The most important natural substrates of PPO in fruits and vegetables are catechins, cinnamic acid esters, 3,4dihydroxy pheylalanine (DOPA), and tyrosine (Vámos-Vigyázó, 1981). The extent to which naturally occurring phenolic substrates contribute to the enzymatic browning of individual fruits or vegetables depends on the localization and concentration of the phenol as well as on the color intensity of the macromeolecular pigments obtained from the different quinones (Mayer \& Harel, 1979). In most fruits and vegetables, phenol concentration is higher in the outer layers (Vámos-Vigyázó, 1981). In apples and pears, the skin contained higher amounts of phenol than the flesh, small fruits had a higher content of phenolics than large fruits, and phenol concentration was higher in winter apples than in summer or in autuunn cultivars (Vámos-Vigyázó, 1981). In carrot, radish, horseradish, and tomato tissue, phenol content was higher in the outer (surface) layers, 
whereas no differences between inner and outer layers were found in phenol content in celery and red beet (Vámos-Vigyázó, 1981). A fundamental difference in the phenolic composition of fruits and vegetables is that catechin, proanthocyanidins (dimers and oligomers of catechins), and leucoanthocyanidins (polyhydroxy-flavan-3,4-diols) are common constituents of most fruits, they occur exceptionally in vegetables (VámosVigyázó, 1981). In edible mushrooms, none of the groups of phenolic compounds present in higher plants could be detected (Mayer \& Harel, 1979). In artichokes, the following phenols have been identified, chlorogenic acid, 1,3-di-o-caffeylquinic acid (cynarine), cryptochlorogenic, neochlorogenic, 3, 5-di-o-caffeylquinic acids, caffeic acid and three falvonoids (luteolin 4'-o-glucoside, luteolin 7-o-glucoside and luteolin 7-o-rhamnoglucoside (Lattanzio \& Van Sumere, 1987). 
CHAPTER 2

JOURNAL ARTICLE 


\section{Authors' Title Page \\ EFFECT OF SELECTED BROWNING INHIBITORS ON}

ARTICHOKE (Cynara scolymus L.) HEADS

Imad H. Ababneh, Panfilo S. Belo*, Miriam Saltmarch, and Lucy McProud Department of Nutrition and Food Science

San Jose State University

1 Washington Square

San Jose, CA 95192-0058

*Address questions and comments to Dr. Panfilo Belo, Department of Nutrition and Food Science, San Jose State University, 1 Washington Square, San Jose, CA 95192-0058, 408-924-3108 


\begin{abstract}
The effectiveness of $0.5 \mathrm{M}$ citric acid $+1 \% \mathrm{H}_{3} \mathrm{PO}_{4}, 0.3 \mathrm{M} \mathrm{CaCl}_{2}+1 \% \mathrm{H}_{3} \mathrm{PO}_{4}$, and $0.5 \mathrm{M}$ citric acid $+0.3 \mathrm{M} \mathrm{CaCl}_{2}+1 \% \mathrm{H}_{3} \mathrm{PO}_{4}$ in controlling browning in fresh artichokes was tested. Artichoke disks were dipped into the three solutions for $1.5 \mathrm{~min}$. Treatments were visually evaluated at $0,3,6$, and 9 days of storage. Disks treated with $0.5 \mathrm{M}$ citric acid $+0.3 \mathrm{M}$ $\mathrm{CaCl}_{2}+1 \% \mathrm{H}_{3} \mathrm{PO}_{4}$ solution showed the least degree of browning. However, visible browning and PPO activity did not correlate. To investigate the low degree of browning in $0.5 \mathrm{M}$ citric acid $+0.3 \mathrm{M} \mathrm{CaCl}_{2}+1 \% \mathrm{H}_{3} \mathrm{PO}_{4}$, water soluble phenolics, water insoluble phenolics and tissue $\mathrm{pH}$ were determined. However, these parameters and degree of browning also did not correlate. The $0.5 \mathrm{M}$ citric acid $+0.3 \mathrm{M} \mathrm{CaCl}_{2}+1 \% \mathrm{H}_{3} \mathrm{PO}_{4}$ treatment was then applied to artichoke heads and the degree of browning was visually evaluated at 0,3 , and 6 days storage. The degree of browning in the treated artichoke heads was less than the control heads. A solution of $0.5 \mathrm{M}$ citric acid $+0.3 \mathrm{M} \mathrm{CaCl}_{2}+1 \% \mathrm{H}_{3} \mathrm{PO}_{4}$ can be used to prevent artichoke discoloration during cold storage.
\end{abstract}

Key Words: Browning inhibition; artichoke; citric acid; cut stems. 


\section{INTRODUCTION}

The shelf life of minimally processed fresh fruits and vegetables is often limited by enzymatic browning (Vámos-Vigyázó, 1981). Both the organoleptic and biochemical characteristics of fruits and vegetables are strongly modified by the appearance of any brown pigments (Vámos-Vigyázó, 1981). Oxidative browning is mainly due to the enzyme Polyphenol oxidase (EC 1.14.18.1) (PPO), a mixed function oxidase which first catalyzes the hydroxylation of monophenols to $o$-diphenols and second oxidizes colorless $o$ diphenols to highly colored o-quinones (Vámos-Vigyázó, 1981). The o-quinones condense spontaneously with other o-quinones and with many constituents of food such as proteins, reducing sugars, etc. to form high molecular weight polymers which precipitate yielding the brown, red, or dark pigments characteristic of browned fruit and vegetable tissues (McEvily et al., 1992). PPO has abroad specificity towards different phenolic substrates and the brown pigments resulting from these phenolics differ greatly in color intensity (Vámos-Vigyázó, 1981)

The enzyme PPO has been extensively studied in fruits and vegetables (VámosVigyázó, 1981). For example, Leoni, Palmieri, Lattanzio, \& Van Sumere (1990) reported the purification and characterization of the enzyme PPO in artichoke heads (Cynara scolymus L.). Artichoke PPO was also reported to be active toward o-diphenols, and has an optimum $\mathrm{pH}$ between 5.0-7.0, and an optimum temperature around $20-30{ }^{\circ} \mathrm{C}$ (Leoni et al., 1990). 
Browning is one of the main causes of quality loss during the post harvest storage of produce (Vámos-Vigyázó, 1981). Tissues of fruits and vegetables are very susceptible to wounding during postharvest handling and processing. Wounding generally induces cellular decompartmentalization which allows mixing of phenolic substrates and PPO, leading to the development of browning (Mayer, 1987). This type of browning can be delayed by storage at low temperatures, but it nevertheless occurs after a lag period (Vámos-Vigyázó, 1981).

Control of browning reaction in fresh produce has been achieved by addition of PPO inhibitors. Historically, enzymatic browning was controlled by the application of sulfites, but the use of sulfites has been banned in raw fruits and vegetables since it can lead to health problems in some individuals (Vámos-Vigyázó, 1981).

Artichokes are a good example of vegetables susceptible to enzymatic browning and this is a major problem encountered during cold storage or display of minimally processed fresh artichokes. The objective of this study was to evaluate the effectiveness of citric acid, calcium chloride, and citric acid+calcium chloride in the presence of phosphoric acid on the inhibition of browning in artichokes stored at refrigerator temperature.

\section{MATERIALS AND METHODS}

Based on our preliminary screening tests, aqueous solutions of $0.5 \mathrm{M}$ citric acid $+1 \% \mathrm{H}_{3} \mathrm{PO}_{4}, 0.3 \mathrm{M} \mathrm{CaCl}_{2}+1 \% \mathrm{H}_{3} \mathrm{PO}_{4}$, and/or $0.5 \mathrm{M}$ citric acid $+0.3 \mathrm{M} \mathrm{CaCl}_{2}+1 \% \mathrm{H}_{3} \mathrm{PO}_{4}$ showed some signs of effective inhibition of browning reaction in artichoke disks prepared 
from artichoke stems. The effectiveness of these three solutions in inhibiting browning reaction was therefore pursued and compared using disks prepared from artichoke stems. Effects of these solutions on browning reaction and PPO activity was evaluated and compared with control at $0,3,6$, and 9 days of storage at refrigerator temperature. Based on the results from these tests, the most effective dipping solution was determined and then tested using whole artichoke heads. Also, the effects on tissue $\mathrm{pH}$, water soluble and insoluble phenolics were studied.

Chemicals. All chemicals used were analytical grade and were obtained either from Sigma Chemical Company (St. Louis, MO) or from the Fisher Scientific Company (Fair Lawn, NJ).

Artichokes. Freshly harvested artichoke heads (c.v Globe) with 8 to $12 \mathrm{~cm}$ stems were obtained from Ocean Mist artichoke fields (Castroville, CA), transported to the laboratory, and stored at $4{ }^{\circ} \mathrm{C}$ prior to use the following day.

Samples preparation, dipping treatment, and storage conditions. Aqueous solutions of $0.5 \mathrm{M}$ citric acid, $0.3 \mathrm{M} \mathrm{CaCl}_{2}$, and $0.5 \mathrm{M}$ citric acid $+0.3 \mathrm{M} \mathrm{CaCl}_{2}$ were prepared. To each solution concentrated phosphoric acid was added to give a final concentration of $1 \%(v / v)$. Artichoke stems showing no external defects were cut with a knife in circular sections ( $3 \mathrm{~cm}$ diameter and $0.5 \mathrm{~cm}$ thickness). Immediately after cutting, the disks were randomly dipped in the dipping solutions or in the water (control) for 1.5 $\min$ and then blotted with soft paper towels and placed on plastic trays and stored at $4{ }^{\circ} \mathrm{C}$. 
Approximately 40 disks were used for each treatment. Degree of browning and PPO activity were monitored at $0,3,6$, and 9 days of storage.

Dipping tests were also performed on whole artichoke heads. Artichoke heads of similar size and no external defects were used. Stems were cut very close to the base of each head and then immediately dipped either in an aqueous solution of $0.5 \mathrm{M}$ citric acid $+0.3 \mathrm{M} \mathrm{CaCl}_{2}+1 \% \mathrm{H}_{3} \mathrm{PO}_{4}$ or in water (control) for $5 \mathrm{~min}$ and then blotted with soft paper towels. Approximately $2 \mathrm{~cm}$ of the top of the head was removed, then immediately dipped in the same dipping solution for an additional $5 \mathrm{~min}$, blotted, and then stored in polyethylene bags at $4^{\circ} \mathrm{C}$. Degree of browning was monitored at 0,3 . and 6 days using a camera.

Effects of $0.5 \mathrm{M}$ citric acid $+0.3 \mathrm{M} \mathrm{CaCl} 2+1 \% \mathrm{H}_{3} \mathrm{PO}_{4}$ treatment on the levels of polyphenols, and tissue $\mathrm{pH}$ were determined using stem disks. Levels of water soluble and water insoluble phenolics were monitored at $0,3,6$, and 9 days at $4{ }^{\circ} \mathrm{C}$.

Degree of browning. Photographs of the artichoke stems and heads were taken at each storage interval by using a Minolta X-700 camera.

Polyphenol oxidase (PPO) activity determination. Enzyme extraction was carried out using the procedure outlined by Coseteng and Lee (1987) with minor modifications. Artichoke disks ( $30 \mathrm{~g}$ ) were homogenized with $75 \mathrm{ml}$ cold acetone in a prechilled Waring blender jar for 5 minutes at maximum speed. The homogenate was filtered through a 
Buchner fiunnel using Whatman No. 1 filter paper. This procedure was repeated at least three times. Then the resulting white acetone powder was freeze dried in a Labconco Freeze Dry/Shell Freeze System (Lyph-Lock6, Kansas City, Missouri) for 10 hours. The freeze dried acetone powder was then stored in the freezer. For PPO extraction, $0.2 \mathrm{~g}$ of freeze dried acetone powder was suspended in $10 \mathrm{ml}$ of $0.05 \mathrm{M}$ Na-phosphate buffer of $\mathrm{pH}$ 6.8. The suspension was then mixed with a magnetic stirrer for $45 \min$ at $4^{\circ} \mathrm{C}$. Next the extract was filtered through Whatman No. 1 filter paper at $4^{\circ} \mathrm{C}$. This crude enzyme was prepared fresh before each activity determination. Protein concentration of the enzyme extracts were determined by Lowry method (Lowry et al., 1951)

Enzyme activity of the PPO extract was determined spectrophotometrically (Shimadzu UV160U spectrophotometer, Kyoto, Japan) at $420 \mathrm{~nm}$. Absorbance values were recorded automatically at 10 second intervals. The activity was assayed in $3 \mathrm{ml}$ of a reaction mixture consisting of $1.5 \mathrm{ml}$ of $0.05 \mathrm{M}$ Na-phosphate buffer (pH 6.8) with $1 \mathrm{ml}$ of $0.1 \mathrm{M}$ catechol prepared in the same buffer and $0.5 \mathrm{ml}$ of prepared enzyme. All of the enzyme assays were performed at $25^{\circ} \mathrm{C}$ in duplicate. Specific activity was defined as the change in the absorbance at $420 \mathrm{~nm} / \mathrm{min} / \mathrm{mg}$ protein.

Effect of dipping solutions on the activity of PPO extracts. Two tests were carried out to determine the effect of the dipping solutions on the activity of crude PPO extracts prepared from untreated artichoke stem disks as described previously. In the first test the 0.05M Na-Phosphate buffer was used as called for in the standard PPO assay. 
Addition of various concentrations of dipping solutions, however, caused the $\mathrm{pH}$ of the various treatments to vary. In order to control the $\mathrm{pH}$ of the assay, a second test using a higher concentration of Na-Phosphate buffer $(0.5 \mathrm{M})$ was used. In both tests the crude enzyme preparation $(0.5 \mathrm{ml})$ was incubated in $0.5 \mathrm{M}$ citric acid $+0.3 \mathrm{M} \mathrm{CaCl} \mathrm{Cl}_{2}+1 \% \mathrm{H}_{3} \mathrm{PO}_{4}$ and/or $0.5 \mathrm{M}$ citric acid $+1 \% \mathrm{H}_{3} \mathrm{PO}_{4}$ for $5 \mathrm{~min}$ at $25^{\circ} \mathrm{C}$. Then PPO activity was measured under standard assay conditions.

Determination of pH. At each storage interval artichoke disks $(10 \mathrm{~g})$ were homogenized in a blender with $20 \mathrm{mls}$ distilled water at a maximum speed for $5 \mathrm{~min}$. The $\mathrm{pH}$ of the sample was measured in duplicate using a digital $\mathrm{pH}$ meter (Model 350 Digital pH/ion analyzer, Corning, New York).

Determination of total phenolics. Total phenolics in the control and $0.5 \mathrm{M}$ citric acid $+0.3 \mathrm{M} \mathrm{CaCl}_{2}+1 \% \mathrm{H}_{3} \mathrm{PO}_{4}$ treated disks were determined using the method of Babic et al. (1993) with minor modifications. Artichoke disks (25 g) were homogenized in $50 \mathrm{ml}$ of an ethanol and water mixture (80:20, v:v). The extract was filtered through Whatman No 4 filter paper and the residue was then treated one more time in the same way. The ethanol was then removed by evaporation at $40^{\circ} \mathrm{C}$ under vacuum. The aqueous extract was then increased to $100 \mathrm{ml}$ with distilled water and then extracted with petroleum ether (50X3) to remove the lipids and pigments. The phenolic compounds were then extracted three times with $50 \mathrm{ml}$ ethyl acetate. The solvent was then evaporated at $40^{\circ} \mathrm{C}$ under vacuum, and the residue was dissolved in $20 \mathrm{ml}$ of distilled water. The water soluble fraction of the mixture 
was used for phenolics determination by enzynatic method. The water insoluble fraction was dissolved in an ethanol and water mixture (80:20, v:v) and used to determine total phenolics as chlorogenic acid by colorimetric method.

Enzymatic determination of water soluble phenolics. Mushroom PPO (EC 1.14.18.1, Sigma, product no.T-7755) was purchased as a dry powder containing 2000 (lot 31F9335) units/mg. One activity unit causes, at $\mathrm{pH} 6.5$ and $25^{\circ} \mathrm{C}$, in a $3 \mathrm{ml}$ reaction mixture containing L-tyrosine, an absorption increase of $0.001 / \mathrm{min}$ at wavelength $280 \mathrm{~nm}$. The enzyme was dissolved in 0.05M Na-Phosphate buffer ( $\mathrm{pH}$ 6.8). For each determination $0.08 \mathrm{mg}$ of the enzyme was used. Enzyme activity was determined spectrophotometrically (Shimadzu UV160U spectrophotometer) at $420 \mathrm{~nm}$; absorbance values were recorded automatically at 10 second intervals. The activity was assayed in $3 \mathrm{ml}$ of reaction mixture, consisting of $2.45 \mathrm{ml}$ of $0.05 \mathrm{M} \mathrm{Na-phosphate} \mathrm{buffer} \mathrm{(pH} \mathrm{6.8)} \mathrm{combined} \mathrm{with} 0.5 \mathrm{ml}$ of sample extract and $0.05 \mathrm{ml}(0.08 \mathrm{mg})$ of the enzyme. All assays were performed in duplicate at $25^{\circ} \mathrm{C}$. The standard curve shown in Fig. 12 was constructed based on 1, 2, 3, 4 , and $5 \mathrm{mg} / \mathrm{ml}$ catechol as a substrate. The plotted values are the average of 3 determinations.

Colorimetric determination of water insoluble phenolics. Total phenolics in the water insoluble fraction were determined using the procedure described by Weurman and Swain (1955). The alcohol extract was diluted to ottain an absorbance reading within the range of the standards $(20-60 \mu \mathrm{g}$ chlorogenic acid/ml). One $\mathrm{ml}$ of the diluted alcohol extract was 
added to $9 \mathrm{ml}$ of distilled water. Then two $\mathrm{ml}$ of $0.2 \mathrm{~N}$ Folin and Ciocalteau Phenol Reagent were added and the sample was mixed. After $5 \mathrm{~min}, 2 \mathrm{ml}$ of saturated sodium carbonate solution were added and the mixture was then agitated. The optical density of the solution at $640 \mathrm{~nm}$ was measured after 1 hr using a Shimadzu UV160U spectrophotometer. The amount of total phenolics was calculated from the standard curve of chlorogenic acid prepared at the same time. All assays were performed in duplicate.

Data analysis. These results were statistically evaluated by using analysis of variance (ANOVA) with significance at $\mathrm{P}<0.05$.

\section{RESULTS AND DISCUSSION}

Photographs of artichoke stem disks dipped in various antibrowning solutions are shown in Figures 1 to 7. Differences in the degree of browning between the control and treated disks are evident from day 0 to day 9 of storage. The degree of browning increased with time of storage with the control showing the highest degree of browning followed by $0.3 \mathrm{M} \mathrm{CaCl}+1 \% \mathrm{H}_{3} \mathrm{PO}_{4}, 0.5 \mathrm{M}$ citric acid $+1 \% \mathrm{H}_{3} \mathrm{PO}_{4}$, and $0.5 \mathrm{M}$ citric acid $+0.3 \mathrm{M} \mathrm{CaCl} 2+1 \% \mathrm{H}_{3} \mathrm{PO}_{4}$. The combined effect of citric acid $+\mathrm{CaCl}_{2}+\mathrm{H}_{3} \mathrm{PO}_{4}$ in the inhibition of the browning reactions is evident. Citric acid $+\mathrm{H}_{3} \mathrm{PO}_{4}$ and $\mathrm{CaCl}_{2}+\mathrm{H}_{3} \mathrm{PO}_{4}$ mixtures were not as effective in inhibiting the browning reaction when compared to the citric acid $+\mathrm{CaCl}_{2}+\mathrm{H}_{3} \mathrm{PO}_{4}$ mixture. These differences maybe attributed to the combined effect of $\mathrm{H}_{3} \mathrm{PO}_{4}$, citric acid, and $\mathrm{CaCl}_{2}$ in lowering the tissue $\mathrm{pH}$, as $\mathrm{Cu}$-chelating agent and as agent in maintaining the integrity of the cell membrane. The role of $\mathrm{pH}$ in the 
browning reactions in fruits and vegetables is well established. Citric acid, phosphoric acid and other acids have been shown to be effective in lowering the $\mathrm{pH}$ of fruits and vegetables thus decreasing the activity of PPO (Vámos-Vigyázó, 1981). As shown in Figure 9, the $\mathrm{pH}$ values of artichoke disks dipped in $0.5 \mathrm{M}$ citric acid $+0.3 \mathrm{M}$ $\mathrm{CaCl}_{2}+1 \% \mathrm{H}_{3} \mathrm{PO}_{4}$ mixture were significantly lower than the control throughout the storage period at refrigeration temperature. On the other hand, citric acid must be considered as a potent sequestering agent. Therefore, the decrease in PPO activity most likely ascribed to the enzyme copper-chelating activity of citric acid (Mayer, 1987). However, the effect of citric acid as a copper-chelating agent on the degree of browning was not noticeable in artichoke disks treated with $0.5 \mathrm{M}$ citric acid $+1 \% \mathrm{H}_{3} \mathrm{PO}_{4}$ solution (Figures 1 to 4 ). On the other hand, the effect of $\mathrm{CaCl}_{2}$ in preventing browning might be due to the membrane integrity preservation. PPO is membrane bound (Mayer, 1987), and is present in latent form in artichoke tissue (Zawistowski et al., 1986; Leoni et al., 1990). When wounding occurs, membranes are degraded and the fatty acids released can activate the latent PPO (Mayer, 1987). The role of calcium might be to preserve membrane integrity and thereby keeping PPO in its inactive form or preventing the cellular decomparmentalization and the mixing of soluble phenolic substrates, which are vacuolar, and membrane-bound PPO. It is noteworthy that some phenols can act as a substrate for both enzymatic and non enzymatic browning (Lattanzio et al., 1989; Leoni et al., 1990). In addition, it is known that phenols with two free $o$-hydroxy groups form colored complexes at pH 6.0 to 6.5 (Lattanzio et al., 1994). Under these conditions chlorogenic acid and 1,5-0-dicaffeoylquinic acid form dark- 
colored complexes with $\mathrm{Fe}^{+3}$ (Lattanzio et al, 1994). Since these compounds are found in extremely high concentrations in artichokes, they are of paramount importance in discoloration (Lattanzio et al., 1989). However, throughout this study the pH values of the treated samples were 3.4 to 4.5 which might be used as evidence to suggest that nonenzymatic browning is unlikely to occur in the treated samples. The degree of browning in the treated artichoke heads was also less than in the control artichoke heads until the sixth day of storage (Figures 5, 6, and 7).

Data from the in vitro determination of PPO activity from extracts of the treated disks are shown in Figure 8. PPO activity did not vary among the treated disks. The low degree of browning in $0.5 \mathrm{M}$ citric acid $+0.3 \mathrm{M} \mathrm{CaCl}_{2}+1 \% \mathrm{H}_{3} \mathrm{PO}_{4}$ treated disks is possibly due to the decrease in $\mathrm{pH}$ which decreased the activity of PPO. This notion was supported by the in vitro determination of PPO activity (Tables 1 and 2). When the dipping solutions were incubated with the crude PPO extract, the activity as well as the pH decreased (Table 1). However, when the $\mathrm{pH}$ was controlled to the optimum $\mathrm{pH}$ of PPO there was no significant difference in the activity between the control group and the incubated enzyme group (Table 2).

Water soluble phenolics, determined by enzymatic method in the control disks and in $0.5 \mathrm{M}$ citric acid $+0.3 \mathrm{M} \mathrm{CaCl}+1 \% \mathrm{H}_{3} \mathrm{PO}_{4}$ treated disks, showed a constant decline throughout the investigation period (Fig. 10). The amount of phenols, determined by the colorimetric method, in $0.5 \mathrm{M}$ citric acid $+0.3 \mathrm{M} \mathrm{CaCl}+1 \% \mathrm{H}_{3} \mathrm{PO}_{4}$ treated disks remained 
almost constant throughout the study, whereas the amount of phenols in the control disks increased slightly (Fig. 11). Changes in water soluble phenolics were monitored because these phenolics are primary substrates for PPO. Water soluble phenolics in both the treated and non-treated disks declined significantly throughout the study (Fig. 10). This decline was accompanied by an increase in the degree of browning in both the treated and the non-treated disks (Figures 1 to 4). This evidence can be used to suggest that the water soluble phenolics acted as the primary substrate for PPO. However, the treated disks showed a higher amount of water soluble phenolics as well as a lower degree of browning. This evidence can be used to suggest that the decrease in the $\mathrm{pH}$ of the treated disks results in a lower rate of substrate degradation due to the low PPO activity. Furthermore, there was a significant difference in the amount of water-insoluble phenolics between the treated and the non-treated disks (Fig. 11). Throughout the study the total water insoluble phenolics was higher in the treated disks. In this study the amount of water insoluble phenolics in the treated disks did not change significantly. However, the control disks showed a significant increase in the amount of water insoluble phenolics by the end of the investigation period. The increase in total phenols was also reported in different plants, including artichokes, after stress conditions such as low temperature storage (Lattanzio et al., 1994) or physical damage (Ke \& Saltveit, 1989). Van Buren et al. (1976) reported that degradation of phenolics occurring during storage as well as formation of browning intermediates such as enediols and reductones resulted in a significant and variable interference with the colorimetric assay. In this study the control disks were subject to 
enzymatic and non-enzymatic browning and such intermediates might occur. Therefore, the concentration of phenolics obtained by the Folin-Ciocalteu procedure, especially in the control group, should be interpreted with caution because non phenolic materials can interfere with the assay.

\section{CONCLUSION}

Artichokes treated with $0.5 \mathrm{M}$ citric acid $+0.3 \mathrm{M} \mathrm{CaCl}_{2}+1 \% \mathrm{H}_{3} \mathrm{PO}_{4}$ showed the lowest degree of browning during the investigation period. The results of the study can be used to suggest that a mixture of $0.5 \mathrm{M}$ citric acid $+0.3 \mathrm{M} \mathrm{CaCl}_{2}+1 \% \mathrm{H}_{3} \mathrm{PO}_{4}$ can be used to increase the shelf life of minimally processed artichoke heads. However, in future studies the organoleptic characteristics of the treated artichoke heads should be performed by trained panelists. Furthermore, in this study there was a lack of correlation between the total phenolics and the degree of browning. The enzymatic and colorimetric procedures used are a general a assessment of the levels of phenolics, therefore future studies should consider specific method for quantitation of individual phenolic compounds such as HPLC. 


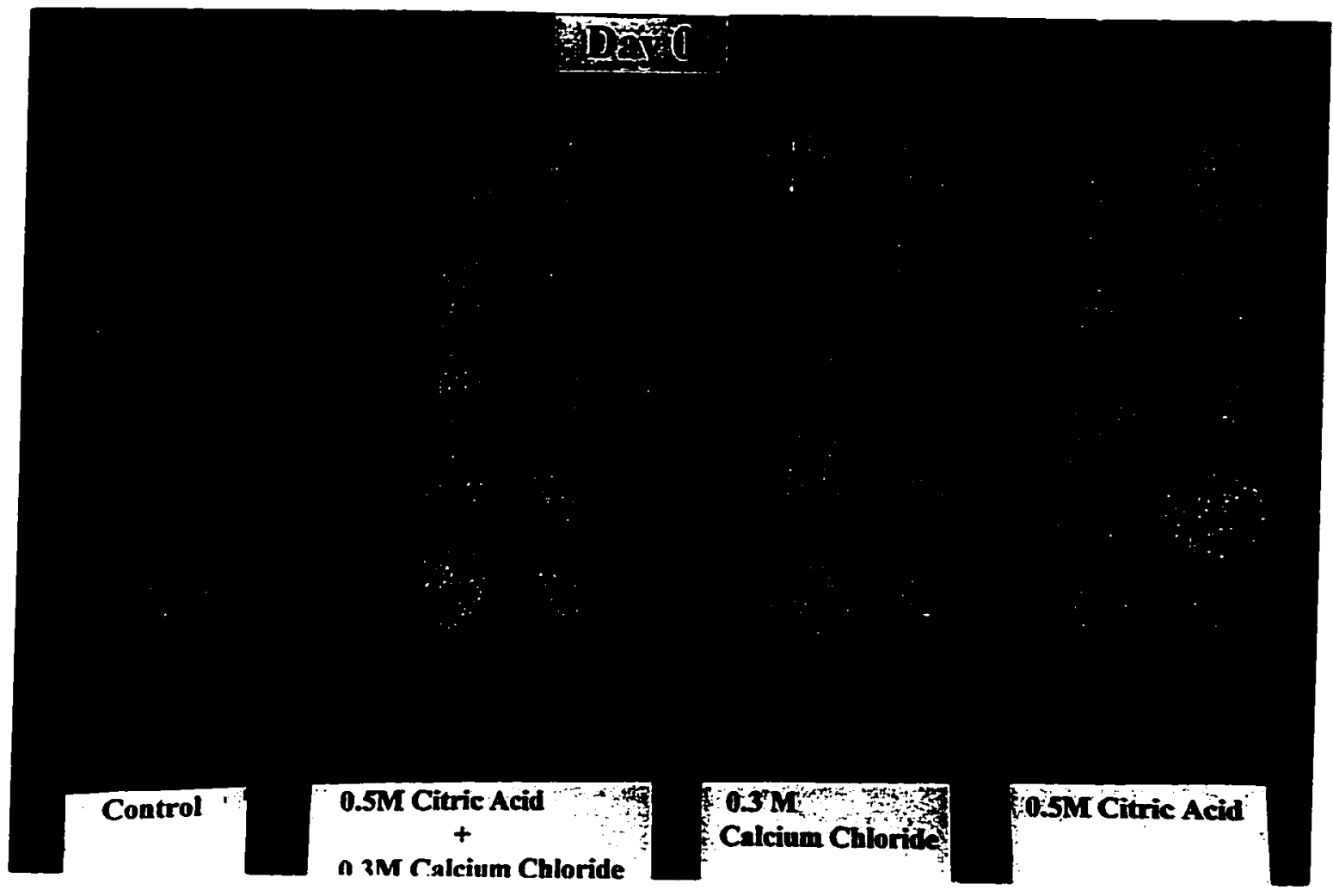

Figure 1. Effects of dipping solutions on degree of browning at 0 day.

Note: Concentrated phosphoric acid was added to each dipping solution except the control to give a final concentration of $1 \%(v: v)$. 


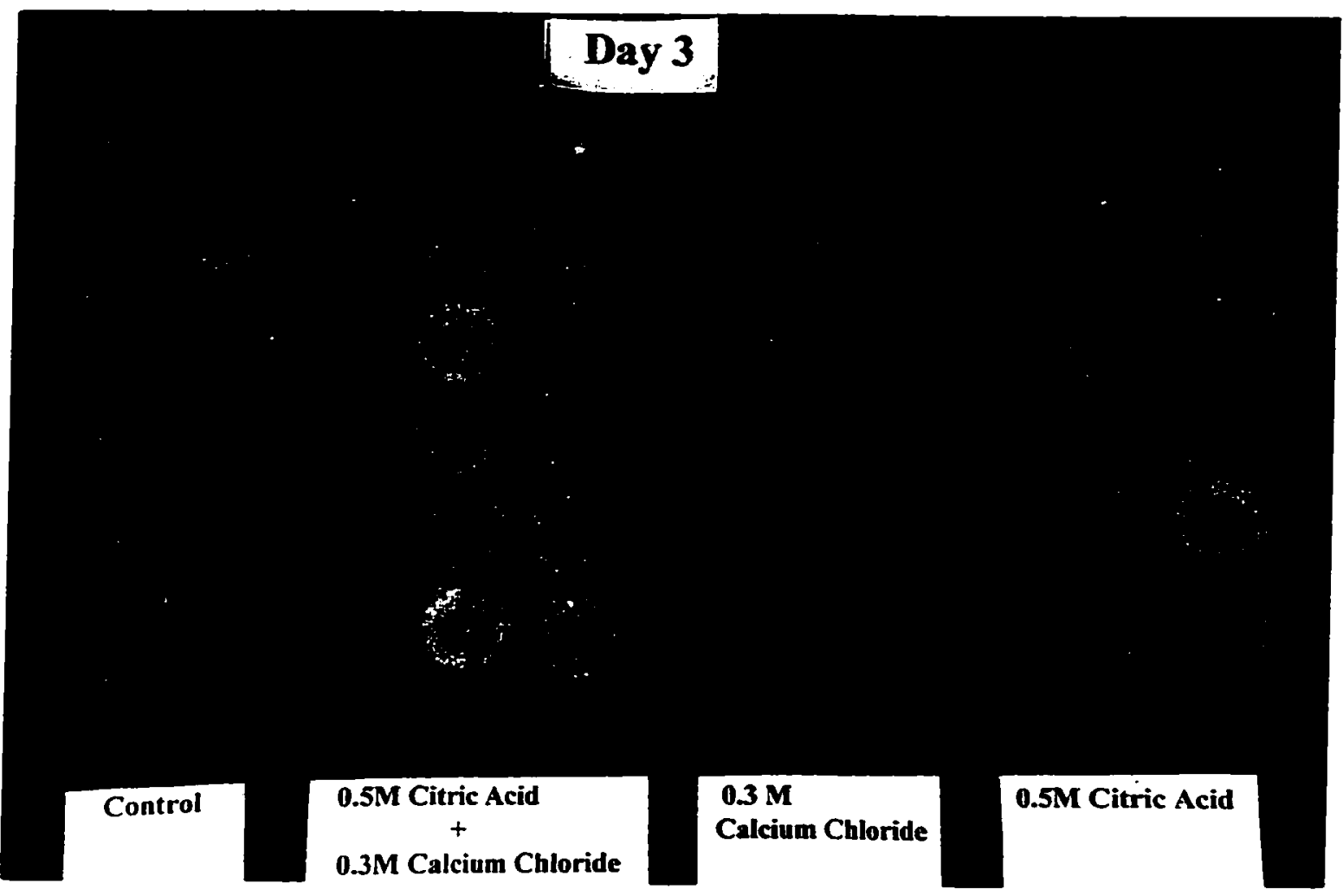

Figure 2. Effects of dipping solutions on degree of browning at 3 days of cold storage.

Note: Concentrated phosphoric acid was added to each dipping solution except the control to give a final concentration of $1 \%(v: v)$. 


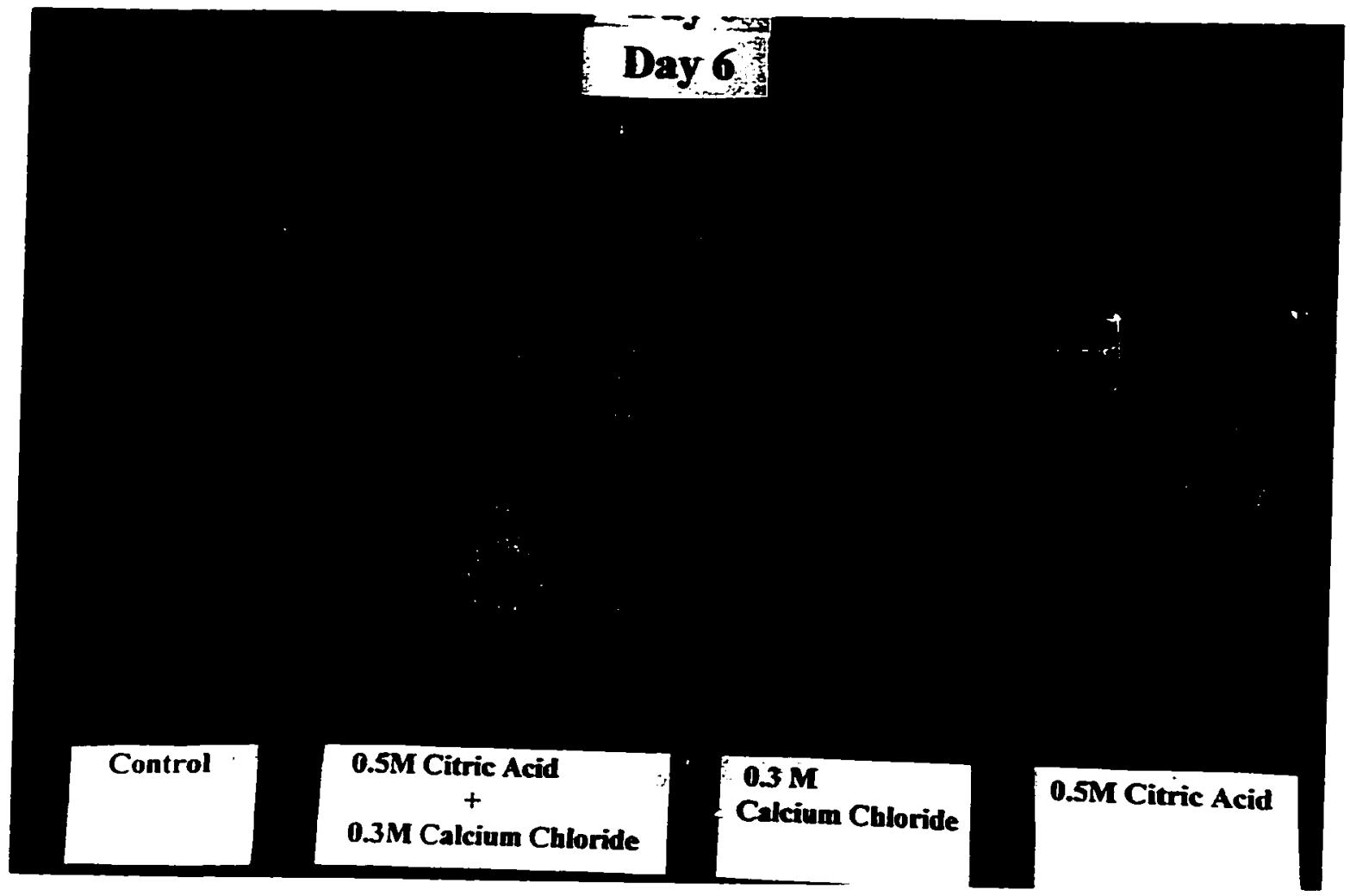

Figure 3. Effects of dipping solutions on degree of browning at 6 days of cold storage.

Note: Concentrated phosphoric acid was added to each dipping solution except the control to give a final concentration of $1 \%(v: v)$. 


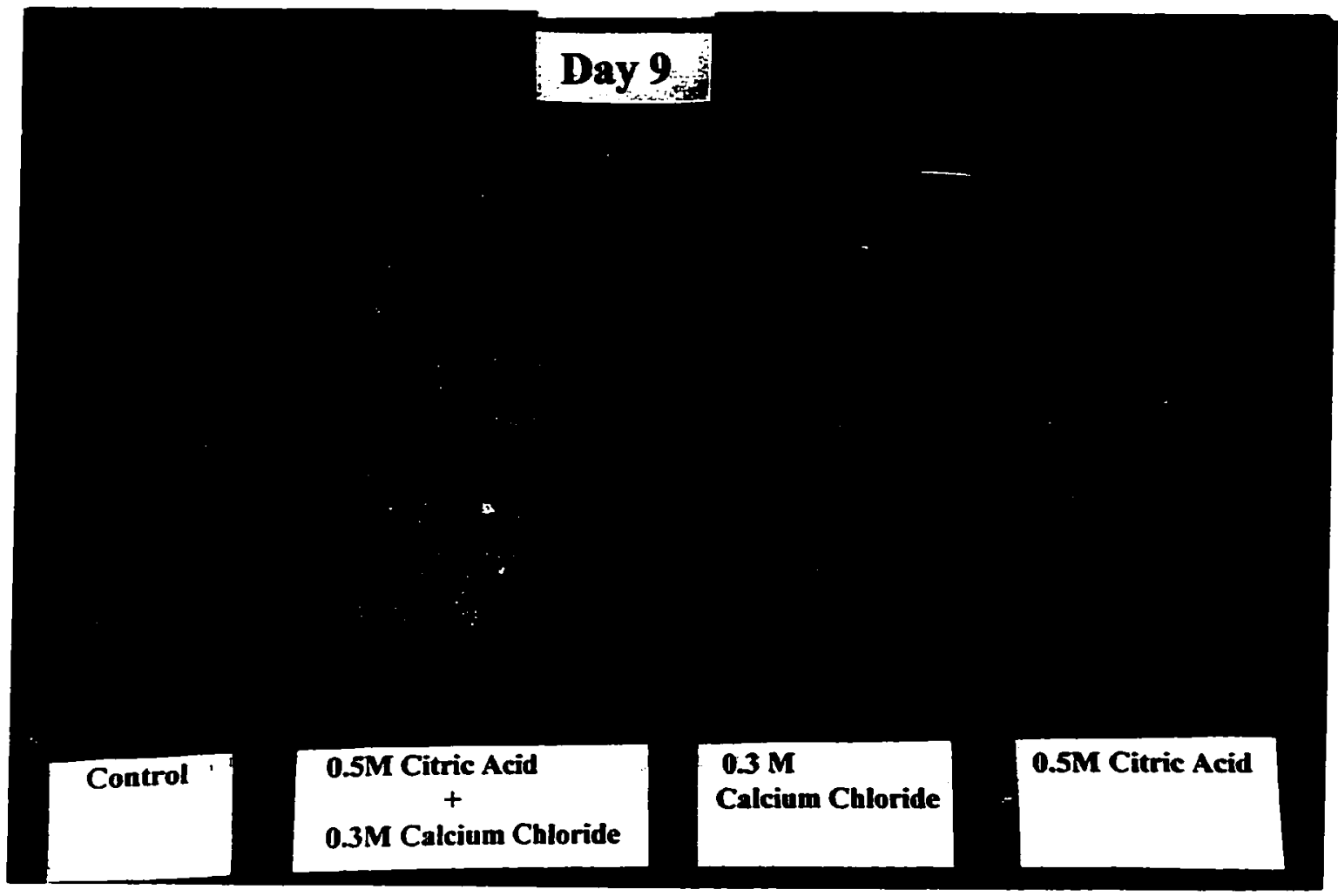

Figure 4. Effects of dipping solutions on degree of browning at 9 days of cold storage.

Note: Concentrated phosphoric acid was added to each dipping solution except the control to give a final concentration of $1 \%(v: v)$. 


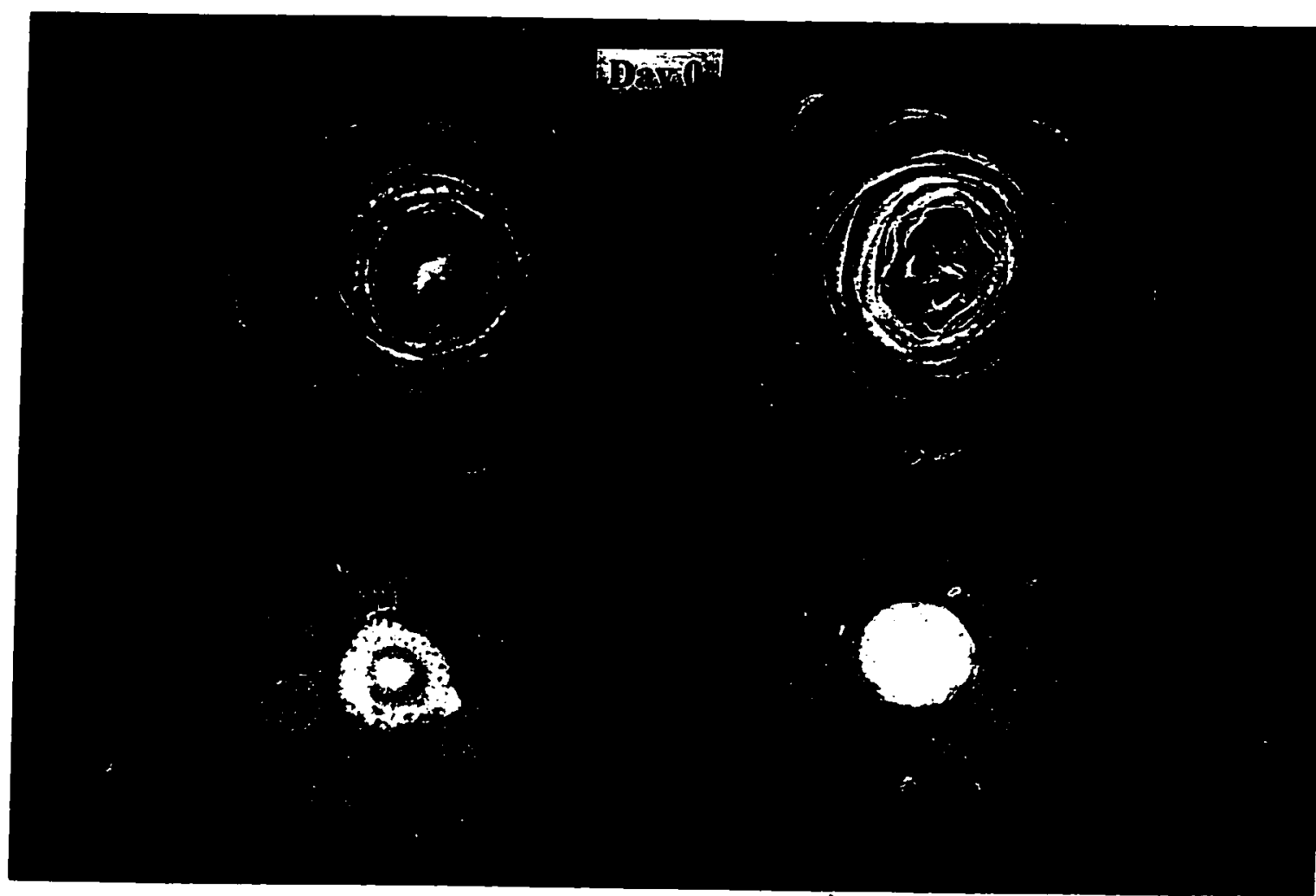

Control

$0.5 \mathrm{M}$ Citric acid $+0.3 \mathrm{M} \quad \mathrm{CaCl}_{2}+1 \% \mathrm{H}_{3} \mathrm{PO}_{4}$

Figure 5. Effect of $0.5 \mathrm{M}$ citric acid $+0.3 \mathrm{M} \mathrm{CaCl}_{2}+1 \% \mathrm{H}_{3} \mathrm{PO}_{4}$ on degree of browning at 0 day. 


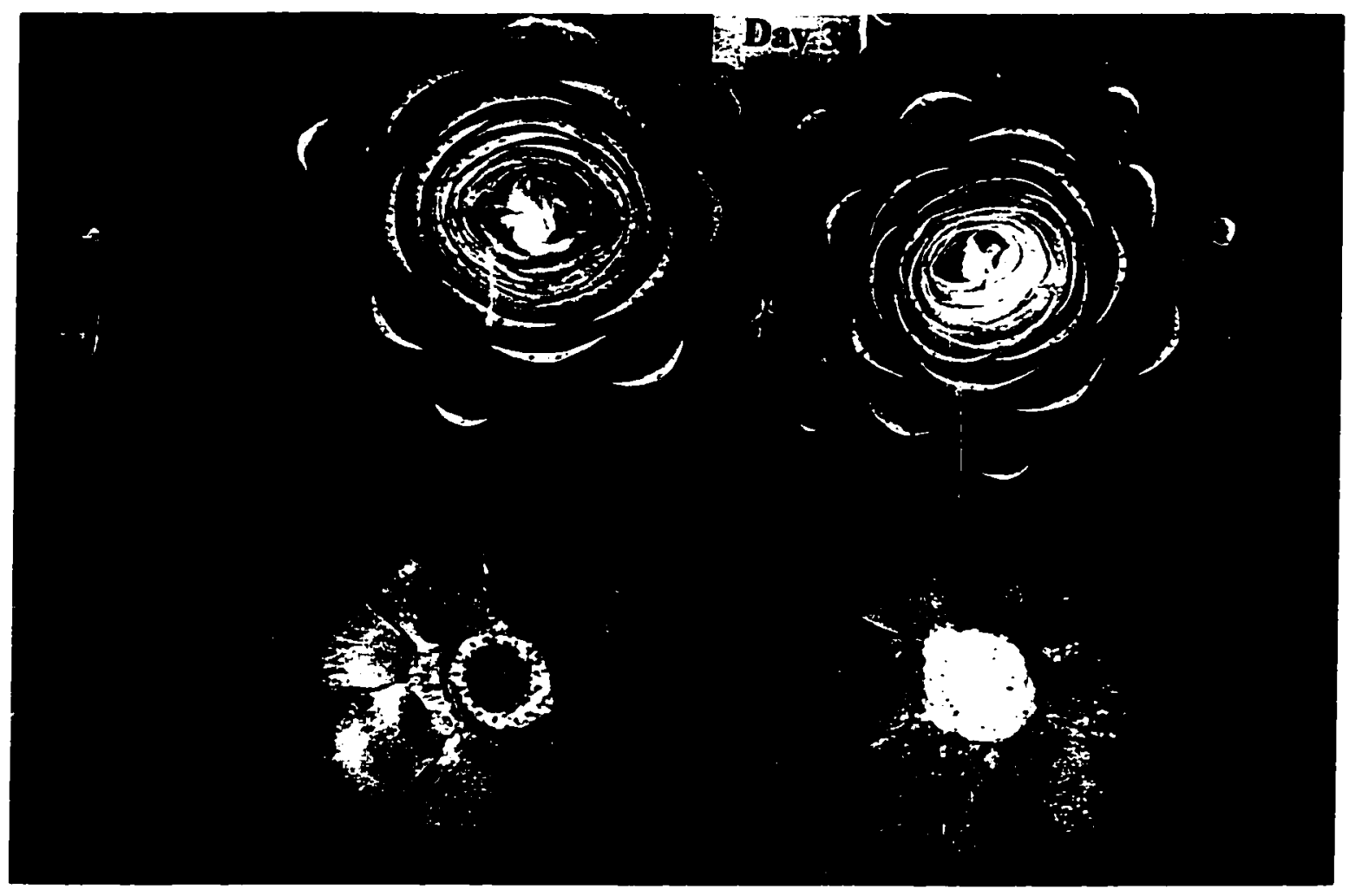

Control

$0.5 \mathrm{M}$ Citric acid+0.3M CaCl $2+1 \% \mathrm{H}_{3} \mathrm{PO}_{4}$

Figure 6. Effect of $0.5 \mathrm{M}$ citric acid $+0.3 \mathrm{M} \mathrm{CaCl}_{2}+1 \% \mathrm{H}_{3} \mathrm{PO}_{4}$ on degree of browning at 3 days of cold storage. 


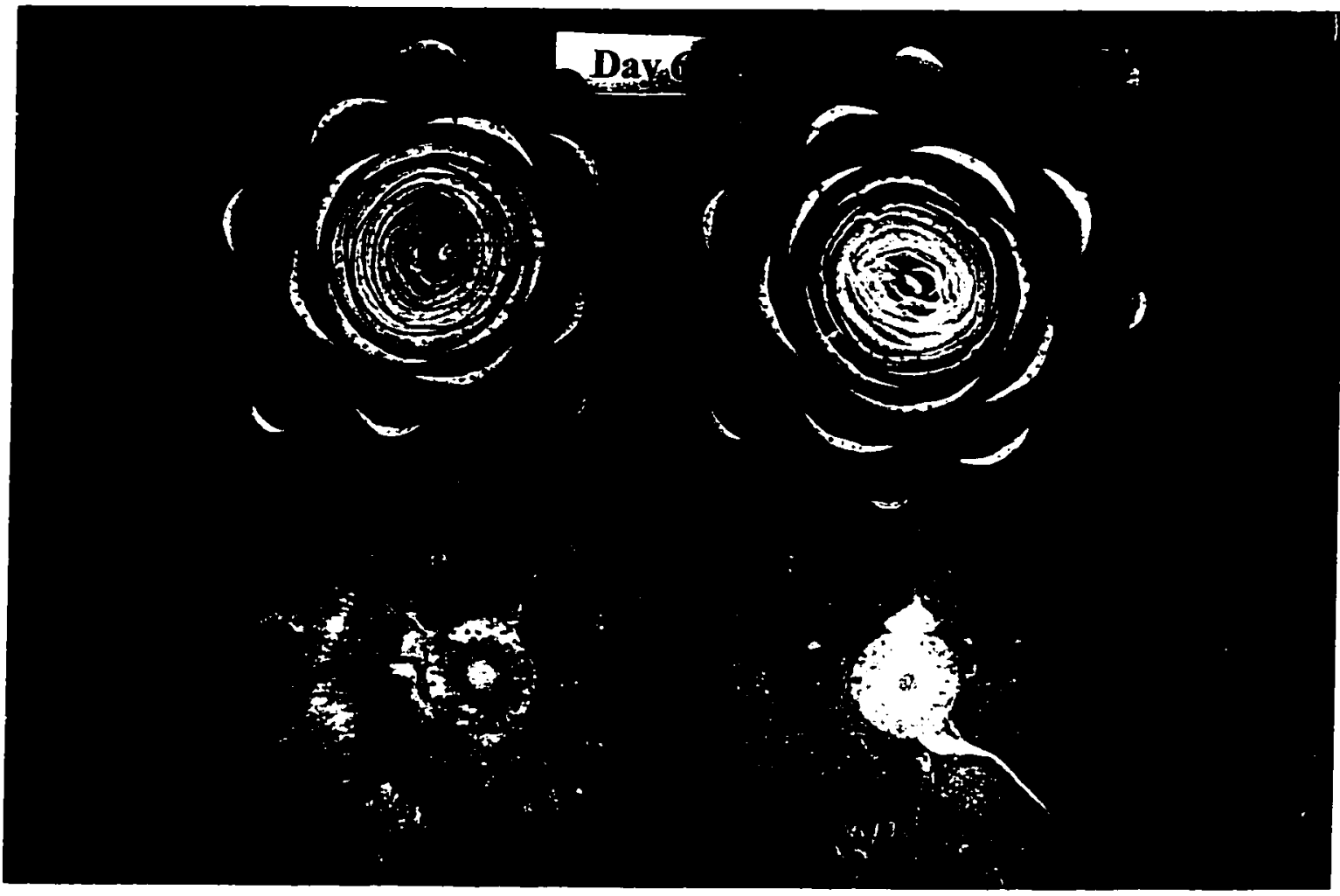

Control

$0.5 \mathrm{M}$ Citric acid $+0.3 \mathrm{M} \mathrm{CaCl}_{2}+1 \% \mathrm{H}_{3} \mathrm{PO}_{4}$

Figure 7. Effect of $0.5 \mathrm{M}$ citric acid $+0.3 \mathrm{M} \mathrm{CaCl}_{2}+1 \% \mathrm{H}_{3} \mathrm{PO}_{4}$ on degree of browning at 6 days c cold storage. 


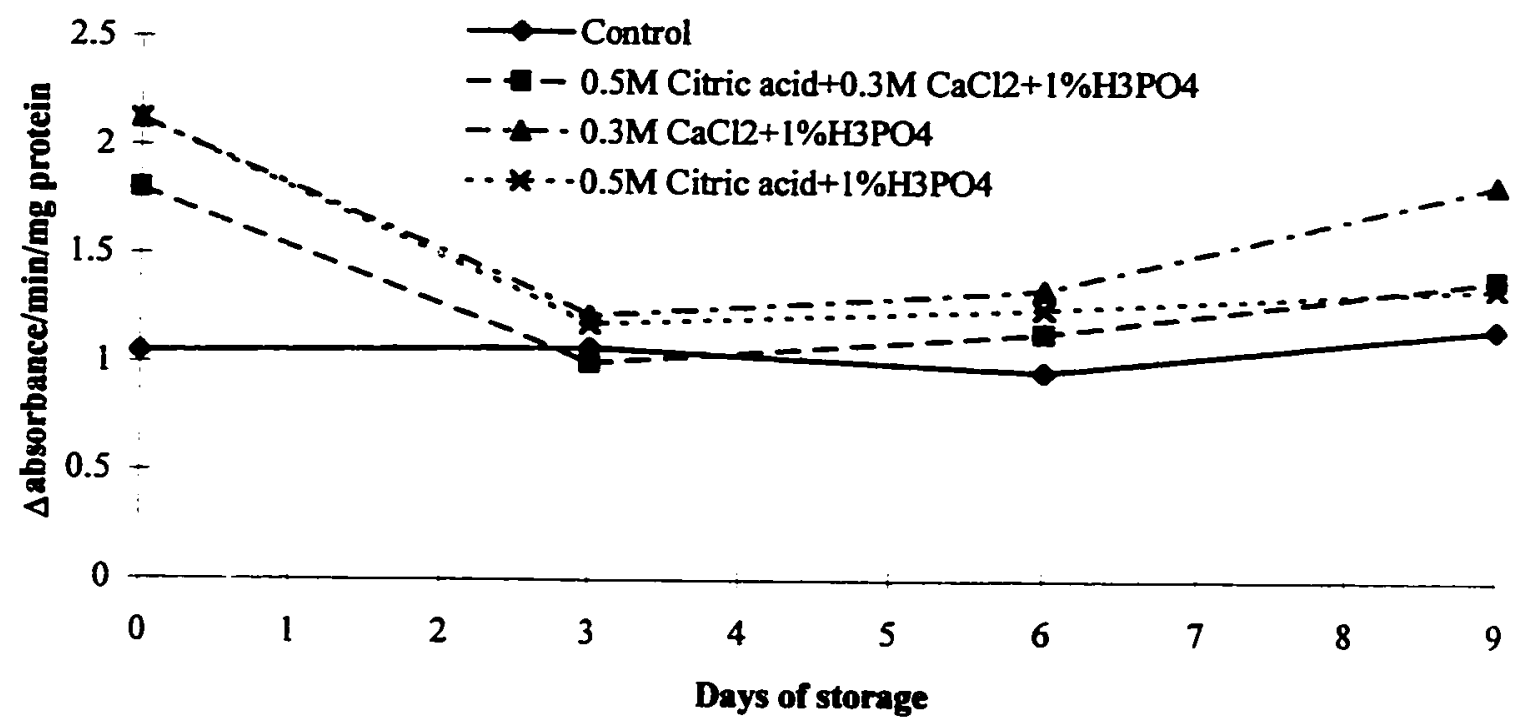

Figure 8. Changes of PPO activity in treated disks during cold storage. 


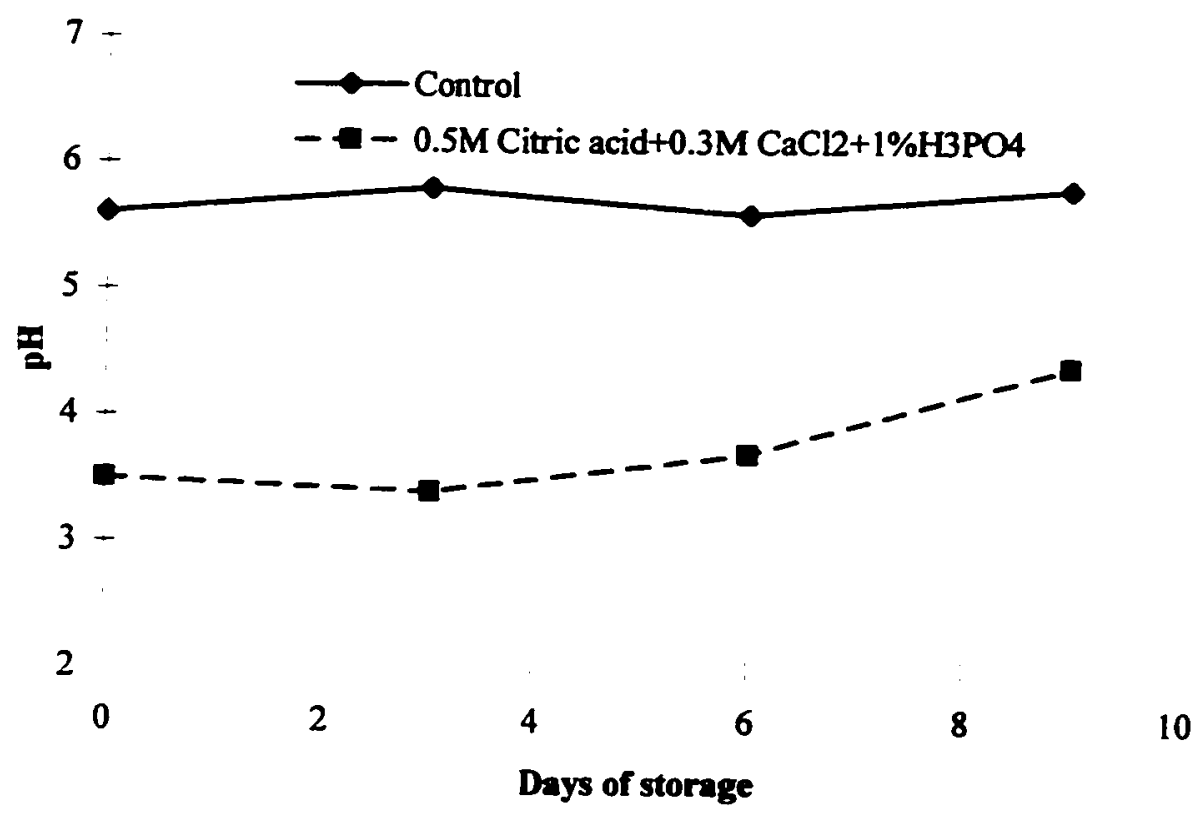

Figure 9. Changes in $\mathrm{pH}$ during cold storage of control disks and $0.5 \mathrm{M}$ Citric acid $+0.3 \mathrm{M}$ $\mathrm{CaCl}_{2}+1 \% \mathrm{H}_{3} \mathrm{PO}_{4}$ treated disks. 


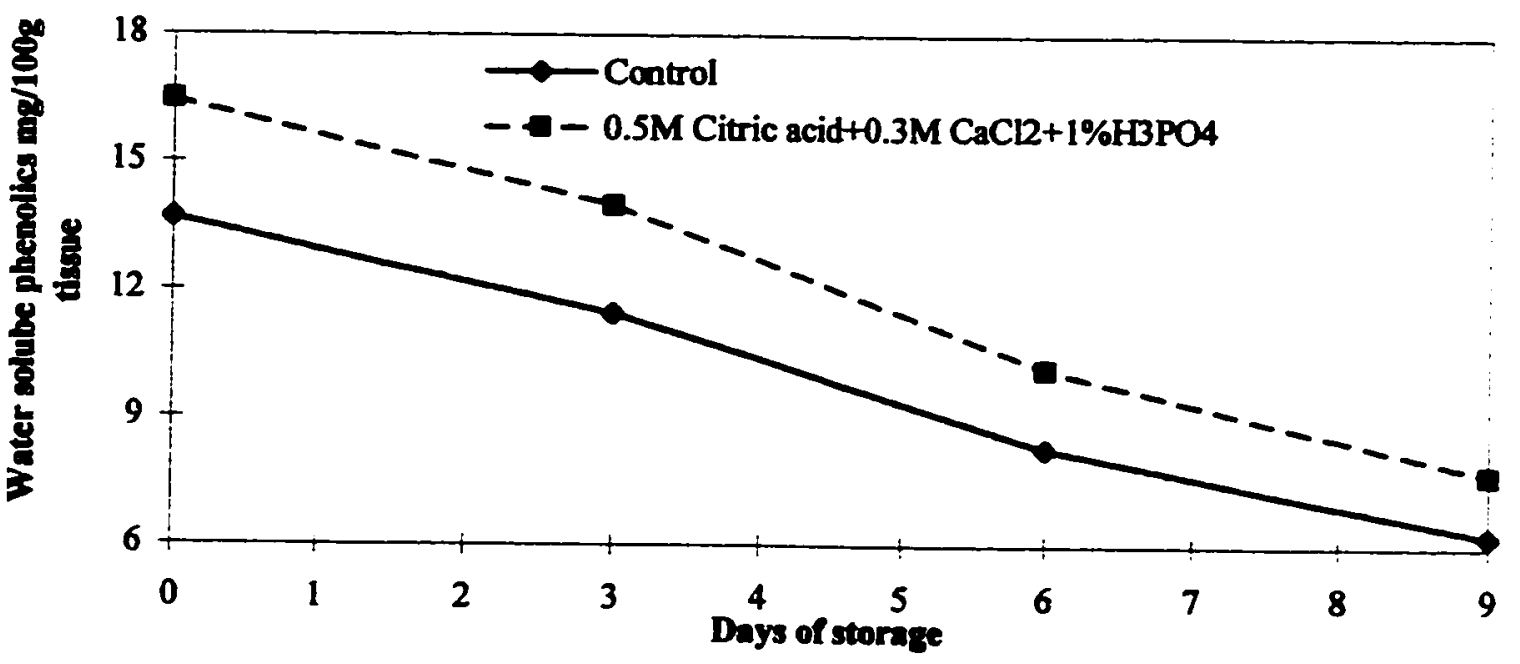

Figure 10. Changes in water soluble phenolics during cold storage of control disks and $0.5 \mathrm{M}$ Citric acid $+0.3 \mathrm{M} \mathrm{CaCl}_{2}+1 \% \mathrm{H}_{3} \mathrm{PO}_{4}$ treated disks. 


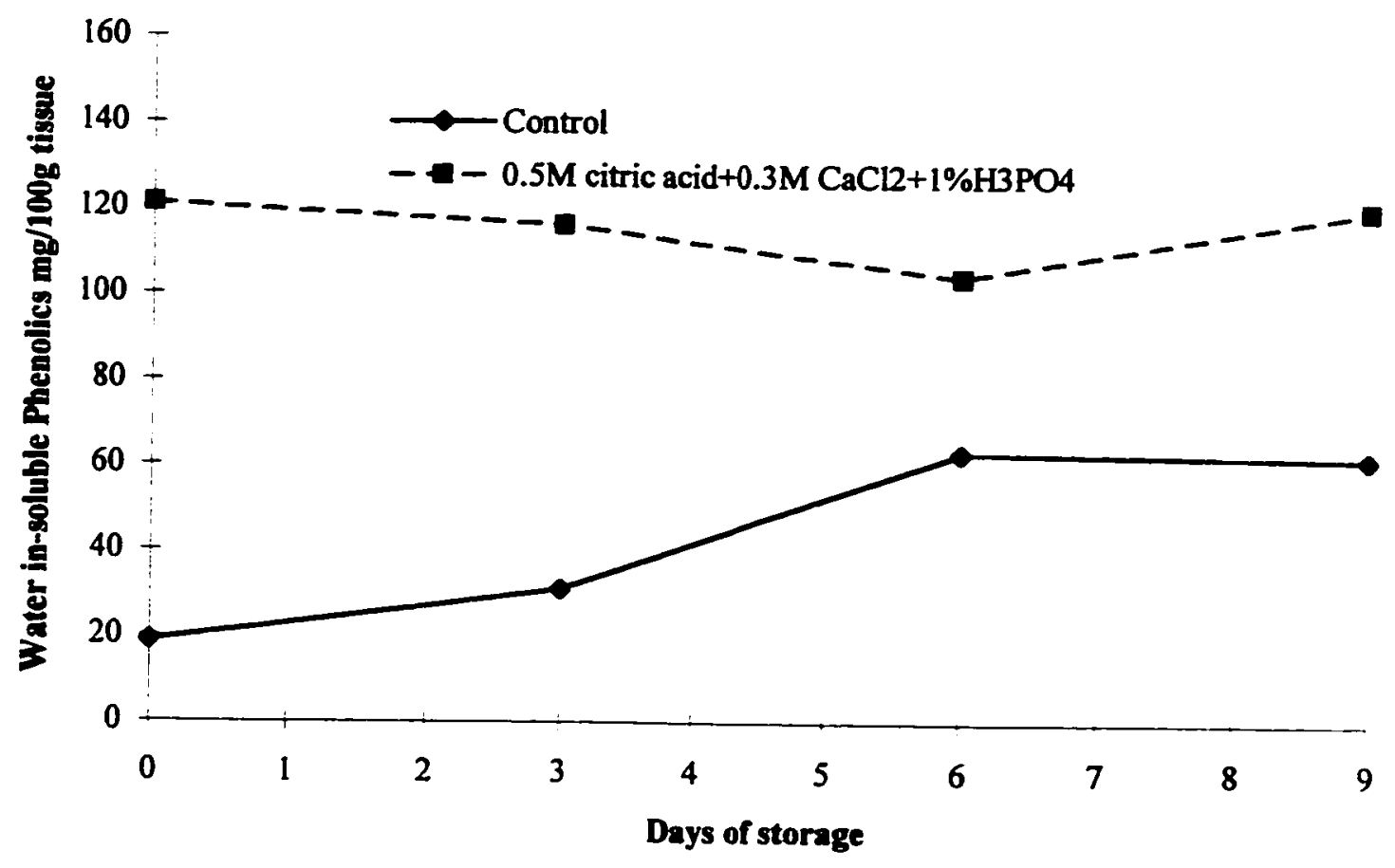

Figure 11. Changes in water insoluble phenolics during cold storage of control disks and $0.5 \mathrm{M}$ Citric acid $+0.3 \mathrm{M} \mathrm{CaCl}_{2}+1 \% \mathrm{H}_{3} \mathrm{PO}_{4}$ treated disks. 


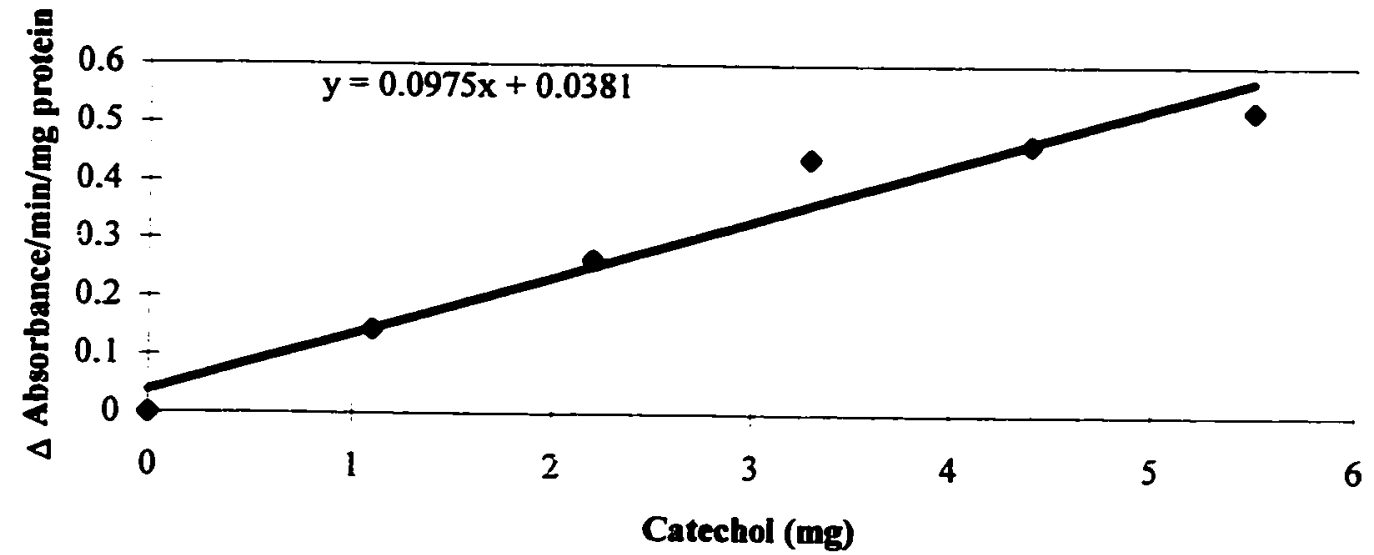

Figure 12. Catechol standard curve. 
Table 1. Effects of Citric acid $+\mathrm{CaCl}_{2}+\mathrm{H}_{3} \mathrm{PO}_{4}$ and Citric $+\mathrm{H}_{3} \mathrm{PO}_{4}$ on the specific activity of crude PPO extract from artichoke stems without maintaining the optimal pH for PPO and using 0.05M Na-Phosphate buffer and catechol as a substrate.

Treatment

Control

Citric acid(33mM)+

$\mathrm{CaC} !_{2}(20 \mathrm{mM})+\mathrm{H}_{3} \mathrm{PO}_{4}(10 \mathrm{mM})$

6.4

Citric acid(83mM)+

$\mathrm{CaCl}_{2}(50 \mathrm{mM})+\mathrm{H}_{3} \mathrm{PO}_{4}(25 \mathrm{mM})$

1.83

Citric acid(33mM)+

$\mathrm{H}_{3} \mathrm{PO}_{4}(10 \mathrm{mM})$

6.5

2.42

Citric acid(83mM)+

$\mathrm{H}_{3} \mathrm{PO}_{4}(25 \mathrm{mM})$

4.5

2.15 
Table 2. Effects of Citric acid $+\mathrm{CaCl}_{2}+\mathrm{H}_{3} \mathrm{PO}_{4}$ and Citric $+\mathrm{H}_{3} \mathrm{PO}_{4}$ on the specific activity of crude PPO extract from artichoke stems and maintaining the optimal pH for PPO and using $0.5 \mathrm{M}$ Na-Phosphate buffer and catechol as a substrate.

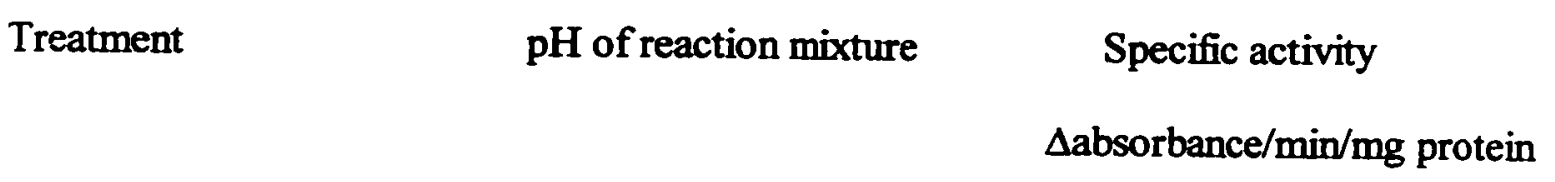

Control

6.80

2.77

Citric acid(33mM)+

$\mathrm{CaCl}_{2}(20 \mathrm{mM})+\mathrm{H}_{3} \mathrm{PO}_{4}(10 \mathrm{mM}) \quad 6.80$

2.75

Citric acid $(83 \mathrm{mM})+$

$\mathrm{CaCl}_{2}(50 \mathrm{mM})+\mathrm{H}_{3} \mathrm{PO}_{4}(25 \mathrm{mM})$

Citric acid(33mM)+

$\mathrm{H}_{3} \mathrm{PO}_{4}(10 \mathrm{mM})$

6.80

Citric acid $(83 \mathrm{mM})+$

$\mathrm{H}_{3} \mathrm{PO}_{4}(25 \mathrm{mM})$

6.78

2.74 


\section{ACKNOWLEDGMENT}

The author would like to thank Ocean Mist farms for supplying the artichokes and San Jose State University, Department of Nutrition and Food Science, San Jose, CA for supporting this work.

\section{LITERATURE CITED}

Babic, I.; Amito, M. J.; Nguyen-The, C.; Aubert, S. Changes in phenolic content in fresh ready-to-use shredded carrots during storage. J. Food Sci. 1993, 58, 351-356.

Coseteng, M. Y.; Lee, C. Y. Changes in apple polyphenol oxidase and polyphenol concentrations in relation to degree of browning. J. Food Sci. 1987, 52, 985-989.

Ke, D.; Saltveit, M. E. Wound-induced ethylene production, phenolic metabolism and susceptibility to russet spotting in iceberg lettuce. Physiol. Plant. 1989, 76, 412-418

Lattanzio, V.; Cardinali, A.; Di Venere, D.; Linsalata, V.; Palmieri, S. Browning phenomena in stored artichoke (Cyanara scolymus L.) heads: enzymic or chemical reaction?. Food Chem., 1994, 50, 1-7.

Lattanzio, V.; Van Sumere, C. F. Changes in phenolic compounds during the development and cold storage of artichoke (Cyanara scolymus L.) heads. Food Chem., 1987, 24, 37-50.

Lattanzio, V.; Linsalata, V.; Palmieri, S.; Van Sumere, C. The beneficial effect of citric acid and ascorbic acid on the phenolic browning reaction in stored artichoke (Cyanara scolymus L.) heads. Food Chem., 1989, 33, 93-106.

Leoni, O.; Palmieri, S.; Lattanzio, V.; Van Sumere, C. F. Polyphenoloxidase from artichoke (Cyanara scolymus L.). Food Chem., 1990 38, 27-39.

Lowry, O. H.; Rosebrough, N. J.; Farr, A. L.; Randal, R. J. Protein measurement with the Folin phenol reagent. $J$ Biol Chem., 1951, 193, 265-275. 
Mayer, A. M. Polyphenol oxidase in plants. Recent progress. Phytochemistry, 1987. 26, 11-20.

McEvily, A. M. J.; Iyengar, R.; Gross, T. Inhibition of polyphenol oxidase by phenolic compounds. In Phenolic Compounds in Food and Their Effects on Health; ACS Symposium Series 507; American Chemical Society: Washington, DC, 1992.

Vámos-Vigyázó, L. Polyphenol oxidase and peroxidase in fruits and vegetables. CRC Crit. Rev. Food Sci. Nutr. 1981, 15, 49-127.

Van Buren, J.; de Vos, L.; Pilnik, W. Polyphenols in golden delicious apple juice in relation to method of preparation. J. Agric. Food Chem. 1976, 24. 448-451.

Weurman, C.; Swain, T. Changes in the enzymic browning of bramiley's seedling apples during their development. J. Sci. Food Agric., 1955, 6, 186-192.

Zawistowski, J.; Blank, G.; Murray, E. D. Polyphenol oxidase activity in Jerusalem artichokes (Helianthus tuberosus L.). Can. Inst. Food Sci. Technol J. 1986, 19, 5, 210-214. 


\section{CHAPTER 3}

\section{SUMMARY AND RECOMMENDATIONS}

\section{Summary}

Browning of damaged tissues of fresh fruits and vegetables during postharvest handling and processing is a main cause of quality loss. The brown color development is related primarily to oxidation of phenolic compounds to $o$-quinones, a reaction catalyzed by Polyphenol oxidase (PPO). These quinones polymerize to form dark brown, black or red polymers. Artichokes are very susceptible to this kind of browning because both the substrate and the enzyme can be found in a high concentrations.

Artichoke disks were treated with different solutions to inhibit browning. These solutions were $0.5 \mathrm{M}$ citric acid $+1 \% \mathrm{H}_{3} \mathrm{PO}_{4}, 0.3 \mathrm{M} \mathrm{CaCl}+1 \% \mathrm{H}_{3} \mathrm{PO}_{4}$ and $0.5 \mathrm{M}$ citric acid $+0.3 \mathrm{M} \mathrm{CaCl}_{2}+1 \% \mathrm{H}_{3} \mathrm{PO}_{4}$. The degree of browning and the PPO activity in treated disks were monitored during 9 days of cold storage. Throughout the study disks treated with $0.5 \mathrm{M}$ citric acid $+0.3 \mathrm{M} \mathrm{CaCl}_{2}+1 \% \mathrm{H}_{3} \mathrm{PO}_{4}$ had the least browning rate when compared to the control and to other treatments. Then the $0.5 \mathrm{M}$ citric acid $+0.3 \mathrm{M} \mathrm{CaCl}_{2}+1 \% \mathrm{H}_{3} \mathrm{PO}_{4}$ solution was applied to the artichoke heads. The heads were cut very close to the base, and then the bases were dipped into the solution for $5 \mathrm{~min}$, after that approximately $2 \mathrm{~cm}$ of the top of the heads were removed, and then immediately dipped in the solution for another $5 \mathrm{~min}$. Artichoke heads treated with $0.5 \mathrm{M}$ citric acid $+0.3 \mathrm{M} \mathrm{CaCl}_{2}+1 \% \mathrm{H}_{3} \mathrm{PO}_{4}$ showed a lower browning rate throughout the study when compared to the control heads. 
Therefore, a solution of $0.5 \mathrm{M}$ citric acid $+0.3 \mathrm{M} \mathrm{CaCl}_{2}+1 \% \mathrm{H}_{3} \mathrm{PO}_{4}$ can be used to prevent artichoke discoloration during cold storage.

\section{Recommendations}

Based on the literature review conducted for this study, this experiment was the first to be carried out on artichoke heads in this manner. This study showed that treating minimally processed artichoke heads with $0.5 \mathrm{M}$ citric acid $+0.3 \mathrm{M} \mathrm{CaCl}_{2}+1 \% \mathrm{H}_{3} \mathrm{PO}_{4}$ solution increased their shelf life by 9 days. However, results of this study can be used to suggest that the $0.5 \mathrm{M}$ citric acid $+0.3 \mathrm{M} \mathrm{CaCl}_{2}+1 \% \mathrm{H}_{3} \mathrm{PO}_{4}$ solution had no effect on PPO and its main effect was in reducing the $\mathrm{pH}$ of the tissue. Therefore, in order to obtain a longer shelf life it might be more beneficial to use some browning inhibitors that act directly on PPO such as carbon monoxide, and sodium diethyl-dithiocarbamate (DIECA).

Sensory evaluation is a crucial part in product development. Therefore, in future studies organoleptic characteristics of the treated artichoke heads should be evaluated by trained panelists.

Finally, packaging of the treated heads should also be investigated to determine the most suitable packaging material for minimally processed artichokes. 


\section{References}

Babic, I., Amito, M. J., Nguyen-The, C., \& Aubert, S. (1993). Changes in phenolic content in fresh ready-to-use shredded carrots during storage. Journal of Food Science, $\underline{58,2}, 351-356$.

Cano, M. P., Lobo, M. G., Ancos, B., \& Galeazzi, A. M. (1996). Polyphenol oxidase from Spanish hermaphrodite and female papaya fruits (Carica papaya cv. Sunrise, solo group). Journal of Agricultural and Food Chemistry 44, 3075-3079.

Coseteng, M. Y., \& Lee, C. Y. (1987). Changes in apple polyphenol oxidase and polyphenol concentrations in relation to degree of browning. Journal of Food Science 52. 4. 985-989. 438-444.

De Vos, N. E. (1992). Artichoke production in California. HortTechnology, 2, 4,

Das, J. R., Bhat, S. G., \& Gowda, L. R. (1997). Purification and characterization of polyphenol oxidase from the kew cultivar of indian pineapple fruit. Journal of Agricultural and Food Chemistry 45, 2031-2035.

El-Shimi, N. (1993). Control of enzymatic browning in apple slices by using ascorbic acid under different conditions. Plant Foods for Human Nutrition, 43, 71-76.

Hammouda, M. M., EL-Naser, S., \& Shahat, A. A. (1993). Flavonoids of Cynara scolymus L. cultivated in Egypt. Plant Foods for Human Nutrition, 44, 163-169.

Ho, Chi-Tang. (1992). Phenolics compounds in food: An overview. In Phenolic Compounds in Food and Their Effects on Health; ACS Symposium Series 507; American Chemical Society: Washington, DC.

Ke, D., \& Saltveit, M. E. (1989). Wound-induced ethylene production, phenolic metabolism and susceptibility to russet spotting in iceberg lettuce. Physiology of Plants, 76, $412-418$

Lattanzio, V., Cardinali, A., Di Venere, D., Linsalata, V., \& Palmieri, S. (1994). Browning phenomena in stored artichoke (Cyanara scolymus L.) heads: enzymic or chemical reaction? Food Chemistry, 50, 1-7.

Lattanzio, V., \& Van Sumere, C. F. (1987). Changes in phoenolic compounds during the development and cold storage of artichoke (Cyanara scolymus L.) heads. Food Chemistry, 24, 37-50. 
Lattanzio, V., Linsalata, V., Palmieri, S., \& Van Sumere, C. (1989). The beneficial effect of citric acid and ascorbis acid on the phenolic browning reaction in stored artichoke (Cyanara scolymus L.) heads. Food Chemistry, 33, 93-106.

Lee, C. Y. (1992). Enzymatic oxidation of phenolic compounds in fruits. In Phenolic Compounds in Food and Their Effects on Health; ACS Symposium Series 507; American Chemical Society: Washington, DC.

Leoni, O., Palmieri, S, Lattanzio, V., \& Van Sumere, C. F. (1990). Polyphenoloxidase from artichoke (Cyanara scolymus L.). Food Chemistry, 38, 27-39.

Lowry, O. H., Rosebrough, N. J., Farr, A. L., \& Randal, R. J. (1951). Protein measurement with the Folin phenol reagent. Journal of Biological Chemistry, 193, 265275.

Mayer, A. M. (1987). Polyphenol oxidase in plants. Recent progress. Phytochemistry, 26, 11-20. 193-215.

Mayer, A. M., \& Harel, E. (1979). Polyphenol oxidase in plants. Phytochemistry, i8,

McEvily, A. M. J., Iyerggar, R., \& Gross, T. (1992). Inhibition of polyphenol oxidase by phenolic compounds. In. Phenolic Cornpounds in Food and Their Effects on Health; ACS Symposium Series 507; American Chemical Society: Washington, DC.

Rainey, C., \& Nyçuist, L. (1997). The California artichoke: Turning over a new leaf for nutrition. Nutritior Today 32, 2, 75-78.

Ranganna, M. (1978). Manial of analysis of fruits and vegetables products. New Delhi, India: Tata 'McGraw Hill Publishing Company Limited.

Sapers, M. G., \& Dougles, F.W. (1987). Measurement of enzymatic browning at cut surface and in juice of raw apple and pear fruit. Journal of Food Science, 52, 1732-1738.

Vámos-Vigyázó, L. (1981). Polyphenol oxidase and peroxidase in fruits and vegetables. CRC Critica?' Reviews in Food Science and Nutrition. 15, 49-127.

Van Buren, J., ds Vos, L., \& Pilnik, W. (1976). Polyphenols in golden delicious apple juice in relation to method of preparation. Journal of Agricultural and Food Chemistry, 24, 3, 448-451.

Vaughn, K. C., \& Duke, S. O. (1984). Function of polyphenol oxidase in higher plants. Physiology of Plants, 60, 106-111. 
Weurman, C., \& Swain, T. (1955). Changes in the enzymic browning of bramiley's seedling apples during their development. Journal of Science and Food Agriculture, 6 , 186-192.

Zawistowski, J., Blank, G., \& Murray, E. D. (1986). Polyphenol oxidase activity in Jerusalem artichokes (Helianthus tuberosus L.). Canadian Institute of Food Science and Technology .ournal 19, 5, 210-214. 